\title{
Transneuronal Labeling of a Nociceptive Pathway, the Spino- (Trigemino-)Parabrachio-Amygdaloid, in the Rat
}

\author{
Luc Jasmin, ${ }^{1}$ Adam R. Burkey, ${ }^{1}$ J. Patrick Card, ${ }^{2}$ and Allan I. Basbaum ${ }^{3}$ \\ ${ }^{1}$ Georgetown University Medical Center, Washington, DC 20007, 2Department of Behavioral Neuroscience, University of \\ Pittsburgh, Pittsburgh, Pennsylvania 15260, and ${ }^{3}$ W. M. Keck Foundation Center for Integrative Neuroscience and \\ Departments of Anatomy and Physiology, University of California, San Francisco, San Francisco, California 94143
}

Transneuronal tracing of a nociceptive pathway, the spino(trigemino)-parabrachio-amygdaloid pathway, was performed using an $\alpha$-herpes virus, the Bartha strain of pseudorabies virus (PRV). Microinjection of PRV into the central nucleus of the amygdala $(\mathrm{Ce})$ resulted in progressive retrograde and transneuronal infection of a multisynaptic circuit involving neurons in the brainstem and spinal cord as detected immunocytochemically. At short survival (26 hr), retrogradely labeled neurons were concentrated in the external lateral nucleus of the parabrachial complex (elPB) but were absent from both the trigeminal nucleus caudalis (TNC) and the spinal cord. At longer survivals (52 $\mathrm{hr}$ ), labeled cells were present in lamina I of both the TNC and spinal dorsal horn. Retrograde labeling from the Ce with Fluorogold demonstrated that elPB neurons have long dendrites extending laterally into the terminal field of spinal and trigeminal afferents, where transneuronal passage of PRV to these afferents could occur. Even longer survivals (76 hr) resulted in a columnar pattern of cell labeling in the TNC and spinal dorsal horn that extended from lamina I into lamina II. At this longest survival, primary sensory neurons became infected. Bilateral excitotoxic lesions of the elPB blocked almost all viral passage from the Ce to superficial laminae of the TNC and spinal dorsal horn. These results demonstrate that nociceptive input to the amygdala is relayed from neurons in lamina I through the elPB. We propose that this modular arrangement of lamina I and II neurons may provide the basis for spinal processing of peripheral input to the amygdala.

Key words: pain pathways; amygdala; superficial dorsal horn; parabrachial nucleus; spinal processing; viral tracer; PRV; pseudorabies virus
The central nucleus of the amygdala $(\mathrm{Ce})$ is the terminal area of a major ascending nociceptive pathway, the spino-(trigemino)parabrachio-amygdaloid tract (Bernard and Besson, 1992). Most Ce neurons respond to noxious, but not innocuous, stimuli (Bernard and Besson, 1990; Bernard et al., 1992). The main source of afferents to the $\mathrm{Ce}$ is the external lateral parabrachial nucleus (elPB) (Saper, 1995). Previous anatomical studies have, however, failed to demonstrate a significant projection from the spinal dorsal horns and trigeminal nucleus caudalis (TNC) to the elPB (Blomqvist et al., 1989). Rather, afferents from nociceptive regions of the dorsal horn, laminae I and $\mathrm{V}$, terminate in nuclei located in the lateral parabrachial area surrounding the elPB, none of which project to the amygdala (Bernard et al., 1995; Feil and Herbert, 1995; Saper, 1995).

To explain this discrepancy, it has been proposed that elPB neurons might have long dendrites that extend into the external nuclear layer where spinal and trigeminal afferents terminate (Blomqvist et al., 1989; Saper, 1995). There is ultrastructural evidence that spinal and trigeminal afferents contact amygdala projection neurons in the lateral parabrachial area (Ma and Peschanski, 1988), but in this study, neither the laminae of origin of the spinal and trigeminal neurons nor the subnuclear location

Received Oct. 28, 1996; revised Feb. 21, 1997; accepted Mar. 3, 1997.

This work was supported by National Institutes of Health Grants 14627 and 21445 (A.I.B.) and RO1DK47523 and the MRC (Canada) (L.J.). A.R.B. is a Howard Hughes Medical Student Fellow. We thank Dr. Kristina Tarczy-Hornoch and Ms Jinwen Tang for their expert technical assistance.

Correspondence should be addressed to Dr. Luc Jasmin, Research Building W221, Georgetown University Medical Center, 3970 Reservoir Road N.W., Washington, DC 20007.

Copyright (C) 1997 Society for Neuroscience $\quad 0270-6474 / 97 / 173751-15 \$ 05.00 / 0$ of these synapses within the lateral parabrachial complex was determined. The possibility remains, therefore, that parabrachial interneurons convey spinal and trigeminal information to the elPB nucleus or that parabrachial nuclei other than the elPB relay nociceptive input to the $\mathrm{Ce}$.

The present study uses pseudorabies virus (PRV), a transneuronal retrograde tracer, to identify the pathway by which nociceptive information is transmitted from the spinal dorsal horn and $\mathrm{TNC}$ to the Ce via the parabrachial nuclei. This virus retrogradely infects synaptically connected neurons in the CNS after injection into various peripheral organs (Card and Enquist, 1994; Loewy, 1995) and, as found more recently, after direct injection in the CNS (Kaufman et al., 1996; O’Donnell et al., 1997). The latter studies, however, revealed problems specific to CNS injection; in particular, it has not been possible to determine the extent of the injection site histologically. Thus, as part of our analysis of the afferent connections of the $\mathrm{Ce}$, we have also performed a rigorous comparison of the extent and pattern of retrograde labeling with traditional tracers injected either alone or coinjected with PRV. Because PRV immunolabeling does not persist at the injection site, we also coinjected PRV with colloidal gold, which permanently labeled the site. Finally, by varying survival times, we were also able to study the temporal pattern of transneuronal transport from the Ce to the parabrachial nuclei and from there to the spinal cord, to the trigeminal nucleus caudalis, and to the trigeminal ganglion cells.

Our results suggest that the input from the spinal cord and trigeminal nucleus caudalis to the $\mathrm{Ce}$ is predominantly from lamina I neurons via connections in the elPB. We also demonstrate that these lamina I projection neurons receive a convergent 

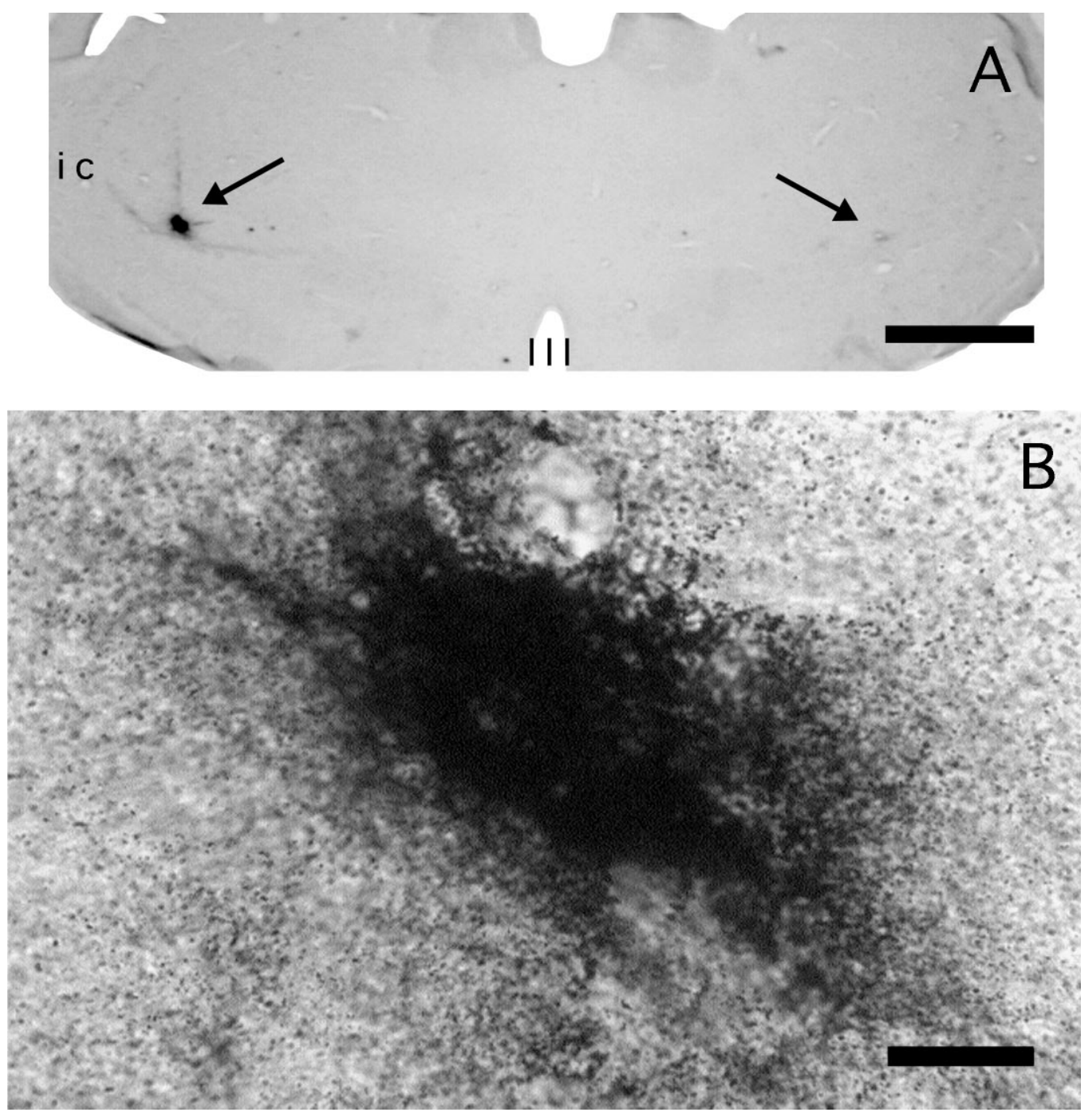

Figure 1. Case 97. Bilateral PRV microinjections into the lateral thalamus (arrows). A, The injection on the left was made 22 min and the one on the right $59 \mathrm{~min}$ before perfusion. Note that the immunoreactivity on the left is well localized, implying a restricted diffusion of the virus. By contrast, little immunoreactivity is present when the survival time was $\sim 1 \mathrm{hr} . B$, The injection on the left side above was imaged at high power, to show the dust-like, noncellular appearance of the immunolabeling. Third ventricle (III); internal capsule (ic). Scale bars: $A, 400 \mu \mathrm{m} ; B, 33 \mu \mathrm{m}$.

innervation from primary sensory neurons and from columns of small cells located in the substantia gelatinosa immediately subjacent to lamina I.

\section{MATERIALS AND METHODS}

Thirty-seven male Sprague Dawley rats (270-300 gm, Bantin and Kingman) were used in the study. All animals were exposed to light $12 \mathrm{hr} / \mathrm{d}$; food and water were available ad libidum. Procedures for the maintenance and use of the experimental animals conformed to the regulations of Georgetown University and the University of California, San Francisco Committees on Animal Research and were performed in accordance with the guidelines of the National Institutes of Health regulations on animal use (National Institutes of Health, 1988).

Tracers. The Bartha strain of PRV (a generous gift from Dr. Lynn Enquist, Princeton University) was used for all experiments that involved virus injections. The Bartha strain is an attenuated strain of PRV that reliably labels various neural pathways via transneuronal transport, including visual (Card et al., 1991), autonomic (Card et al., 1990; Strack and Loewy, 1990), and somatic pathways (Martin and Dolivo, 1983; Rouiller et al., 1986; Jasmin et al., 1997). The titer of the virus was $1 \times 10^{8} \mathrm{pfu} / \mathrm{ml}$ of culture medium. Aliquots $(100 \mu \mathrm{l})$ of the virus were kept in the freezer $\left(-80^{\circ} \mathrm{C}\right)$, and, on each experimental day, an aliquot was thawed and kept on ice until injected. Fluoro-gold (Fluorochrome Inc., Englewood, CO) was used at a dilution of $4 \%$ in double-distilled water. Cholera toxin B (List Biological Lab, Campbell, CA) was used at a dilution of $1 \%$ in the virus suspension.

Surgery. During the surgical procedure, the animals were maintained under anesthesia with a mixture of ketamine $(60 \mathrm{mg} / \mathrm{kg})$ and xylazine $(7.0$ $\mathrm{mg} / \mathrm{kg}$ ) injected intramuscularly. For surgeries lasting more than $40 \mathrm{~min}$, an additional dose of ketamine $(20 \mathrm{mg} / \mathrm{kg})$ was given. Animals were placed in a stereotaxic apparatus (David Kopf Instruments) using nonperforating ear bars. Coordinates for the central nucleus of amygdala (rostrocaudal, 6.2; mediolateral, 4.3; dorsoventral, 7.2) and lateral parabrachial area, (rostrocaudal, 0.16; mediolateral, 2.1; dorsoventral, 6.3) were taken from the atlas of Paxinos and Watson (1986) using the interaural reference point. Injections were made with a glass micropipette with a tip diameter of $40 \mu \mathrm{m}$ connected to a $1 \mathrm{ml}$ Hamilton syringe. A small burr hole was made above the target, the dura mater was then opened, and the pipette was directed stereotaxically to the target. The tracer (Table 1) was injected slowly over $20 \mathrm{nl} / \mathrm{min}$ into the right amygdala or lateral parabrachial area. The pipette was left in the brain for an additional $15 \mathrm{~min}$; this waiting period prevented tracer leakage along the injection tract. For virus injection, care was taken to clean the external surface of the pipette after loading to minimize the chance of inoculation of the brain surface or the tissue along the pipette's trajectory.

We injected $100 \mathrm{nl}$ of PRV into the ventral posteromedial nucleus (VPM) 


\begin{tabular}{|c|c|c|c|}
\hline Case & Target & Volume injected (nl) & Survival \\
\hline 1 & $\mathrm{Ce}$ & $200 \mathrm{PRV}$ & $48 \mathrm{hr}$ \\
\hline 8 & $\mathrm{Ce}$ & 200 PRV & $52 \mathrm{hr}$ \\
\hline 26 & $\mathrm{Ce}$ & 200 PRV & $48 \mathrm{hr}$ \\
\hline 40 & $\mathrm{Ce}$ & 300 PRV & $48 \mathrm{hr}$ \\
\hline 46 & $\mathrm{Ce}$ & $200 \mathrm{PRV}+1 \% \mathrm{CTB}$ & $48 \mathrm{hr}$ \\
\hline 47 & $\mathrm{Ce}$ & 200 PRV & $26 \mathrm{hr}$ \\
\hline 48 & $\mathrm{Ce}$ & 200 PRV & $82 \mathrm{hr}$ \\
\hline 49 & $\mathrm{Ce}$ & 200 PRV & $48 \mathrm{hr}$ \\
\hline 50 & $\mathrm{Ce}$ & 200 PRV & $96 \mathrm{hr}$ \\
\hline 51 & Lateral PB & $200 \mathrm{PRV}+1 \% \mathrm{CTB}$ & $96 \mathrm{hr}$ \\
\hline 52 & Lateral PB & 200 PRV & $75 \mathrm{hr}$ \\
\hline 60 & $\mathrm{Ce}$ & $50 \mathrm{FG}$ & $7 \mathrm{~d}$ \\
\hline 61 & $\mathrm{Ce}$ & $40 \mathrm{FG}$ & $7 \mathrm{~d}$ \\
\hline 62 & $\mathrm{Ce}$ & $40 \mathrm{FG}$ & $7 \mathrm{~d}$ \\
\hline 67 & $\mathrm{Ce}$ & $40 \mathrm{FG}$ & $7 \mathrm{~d}$ \\
\hline 69 & Lateral PB & $50 \mathrm{PRV}$ & $120 \mathrm{hr}$ \\
\hline 70 & $\mathrm{Ce}$ & $50 \mathrm{PRV}$ & $72 \mathrm{hr}$ \\
\hline 71 & $\mathrm{Ce}$ & $40 \mathrm{FG}(4 \%)$ & $7 \mathrm{~d}+72 \mathrm{hr}$ \\
\hline 71 & $\mathrm{Ce}$ & $50 \mathrm{PRV}$ & $72 \mathrm{hr}$ \\
\hline 85 & Right VPM & $200 \mathrm{PRV}$ & $76 \mathrm{~min}$ \\
\hline 85 & Left VPM & $200 \mathrm{PRV}+1 \mathrm{CTB}$ & $27 \mathrm{~min}$ \\
\hline 86 & Left VPM & $200 \mathrm{PRV}+1 \% \mathrm{CTB}$ & $66 \min$ \\
\hline 86 & Right VPM & 200 PRV & $22 \mathrm{~min}$ \\
\hline 87 & Left VPM & $100 \mathrm{PRV}+1 \% \mathrm{CTB}$ & $65 \mathrm{hr}$ \\
\hline 88 & Left VPM & 100 PRV & $66 \mathrm{hr}$ \\
\hline 89 & Left VPM & 100 PRV & $77 \mathrm{hr}$ \\
\hline 91 & Left VPM & 100 PRV & $72 \mathrm{hr}$ \\
\hline 92 & Left VPM & 100 PRV & $72 \mathrm{hr}$ \\
\hline 93 & $\mathrm{Ce}$ & 100 PRV & $52 \mathrm{hr}$ \\
\hline 94 & $\mathrm{Ce}$ & 100 PRV & $52 \mathrm{hr}$ \\
\hline 95 & $\mathrm{Ce}$ & 100 PRV & $52 \mathrm{hr}$ \\
\hline 100 & Lateral PB & $40 \mathrm{CTB}$ & $7 \mathrm{~d}+72 \mathrm{hr}$ \\
\hline 100 & $\mathrm{Ce}$ & 100 PRV & $72 \mathrm{hr}$ \\
\hline 101 & Lateral PB & $40 \mathrm{CTB}$ & $7 \mathrm{~d}+96 \mathrm{hr}$ \\
\hline 101 & $\mathrm{Ce}$ & 100 PRV & $96 \mathrm{hr}$ \\
\hline 102 & Lateral PB & 40 СТВ & $7 \mathrm{~d}+48 \mathrm{hr}$ \\
\hline 102 & $\mathrm{Ce}$ & 100 PRV & $48 \mathrm{hr}$ \\
\hline 103 & Lateral PB & 80 PRV & $56 \mathrm{hr}$ \\
\hline 104 & Lateral PB & $80 \mathrm{PRV}$ & $72 \mathrm{hr}$ \\
\hline 105 & Lateral PB & 80 PRV & $72 \mathrm{hr}$ \\
\hline 1501 & $\mathrm{Ce}$ & 200 PRV & $90 \mathrm{hr}$ \\
\hline 1508 & $\mathrm{Ce}$ & 200 PRV & $94 \mathrm{hr}$ \\
\hline 1510 & $\mathrm{Ce}$ & 200 PRV & $78.5 \mathrm{hr}$ \\
\hline
\end{tabular}

$\overline{\text { For all injections } 20 \% \text { of concentrated colloidal gold was added to each volume of }}$ PRV except when PRV was coinjected with CTB (cases 46, 85, 86, 87).

For cases $85,86,100,101$, and 102, FG or CTB were injected $7 \mathrm{~d}$ before PRV injection.

For cases 1501, 1508, and 1510, bilateral excitotoxic of the elPB were made $7 \mathrm{~d}$ before PRV injection.

Central nucleus of the amygdala (Ce); Cholera Toxin (CTB); Fluoro-Gold (FG); (PB) parabrachial; PRV, Bartha strain of pseudorables virus; VPM, ventroposteromedial nucleus of thalamus.

of the thalamus and evaluated the pattern of labeling in the caudal medulla $36 \mathrm{hr}$ later to provide a second method of assessing the radius of viral uptake. Neurons that project to VPM are located in the trigeminal nucleus caudalis of the caudal medulla, whereas neurons that project to the VPL (immediately adjacent to VPM) arise from the dorsal column nuclei, located adjacent to the trigeminal nucleus caudalis. Thus, if the virus had diffused from the VPM to the VPL and had been taken up and transported by VPL axons, we would record labeled neurons in the dorsal column nuclei as well as the
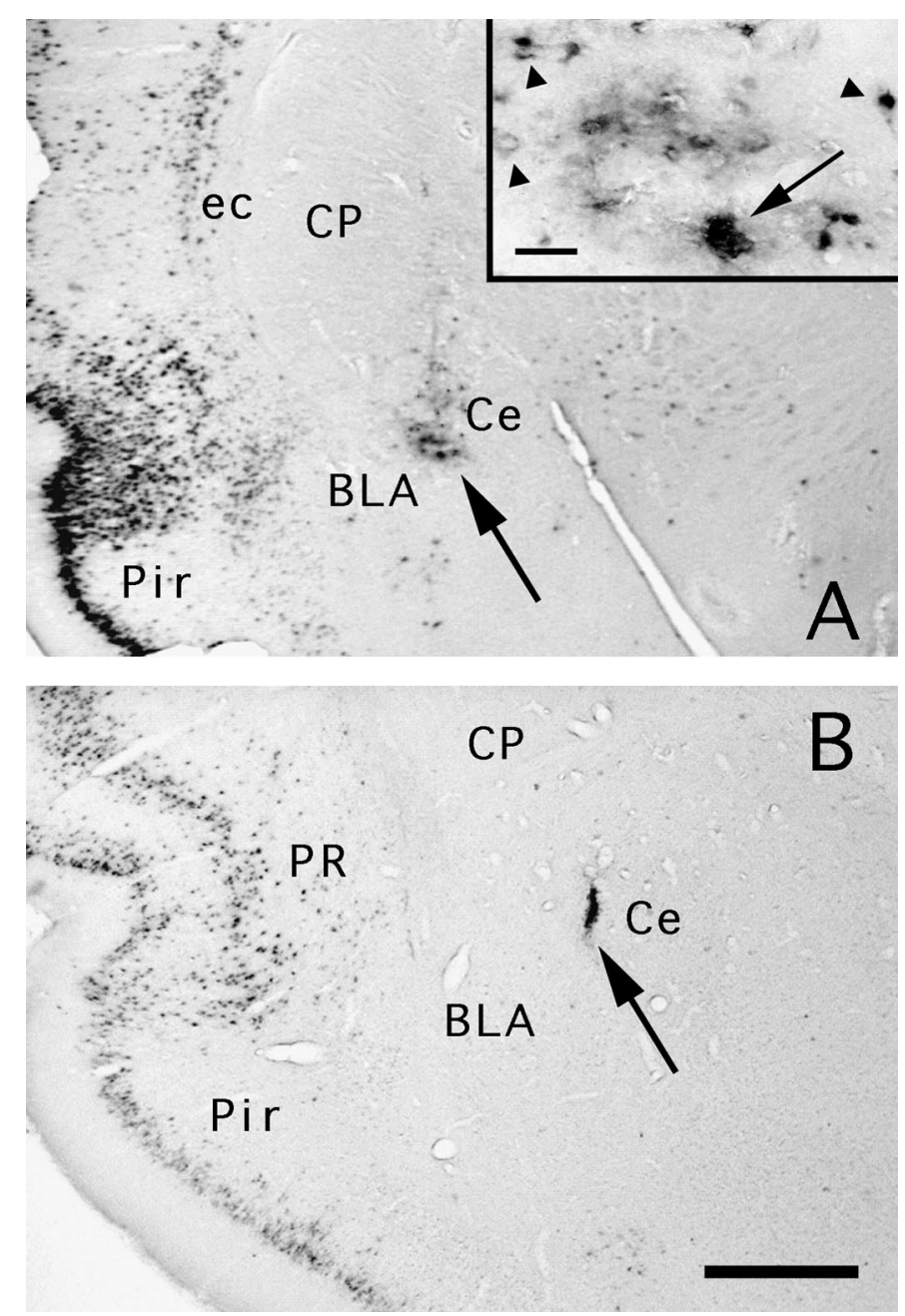

Figure 2. A, Case 47. After $26 \mathrm{hr}$, PRV-immunoreactive neurons are visible at the injection site (arrow) in cell bodies. The inset shows PRV immunolabeled cell profiles (arrowheads) and colloidal gold (arrow). Compare with the dust-like immunoreactivity in Figure $1 B . B$, Case 93. An example of a PRV injection site in the Ce (lateral division) at $52 \mathrm{hr}$. The injection site is localized by gold particles, which persist after coinjection with the virus. PRV immunoreactivity is no longer found at the injection site as in $A$, which is likely attributable to clearance of the virus by an immune response (Rinaman et al., 1993; Card and Enquist, 1995). Labeled cells are visible in the perirhinal $(P R)$ and piriform cortex (Pir); these presumably resulted from both direct and transneuronal transport. Basolateral amygdaloid nucleus $(B L A)$; central nucleus $(C e)$; caudate putamen $(C P)$; external capsule (ec). Scale bars: $A$ (inset), $33 \mu \mathrm{m} ; A, 250$ $\mu \mathrm{m} ; B, 150 \mu \mathrm{m}$.

trigeminal nucleus caudalis. There are, to our knowledge, no projections from the VPL to the VPM that would allow transneuronal passage of the virus from the VPM to the dorsal column nuclei via the VPL.

Lesion studies. Bilateral lesions of the elPB were produced by microinjection (with a $50 \mu \mathrm{m}$ tip glass pipette) of $500 \mathrm{nl}$ of an aqueous solution containing $0.5 \%$ ibotenic acid (Sigma, St. Louis, MO) in three rats (1501, 1508 , and 1510). Each injection was made over a 15 min period while the animal was under general anesthesia. Ibotenic acid is an analog of the excitatory neurotransmitter glutamic acid. It has been shown to create discrete cellular lesions when injected in the cerebral cortex (Iadecola et al., 1987; Meunier and Destrade, 1988). One week later the animals were injected with $200 \mathrm{nl}$ of PRV and colloidal gold in the left amygdala and perfused 90, 94, and $78.5 \mathrm{hr}$ later, respectively. To define the extent of the ibotenic acid lesions, a Nissl stain and PRV immunocytochemistry were performed on transverse sections of the parabrachial area.

Postoperative period. After recovering from surgery, the animals were returned to their cages and brought back to the animal facility. Those rats 

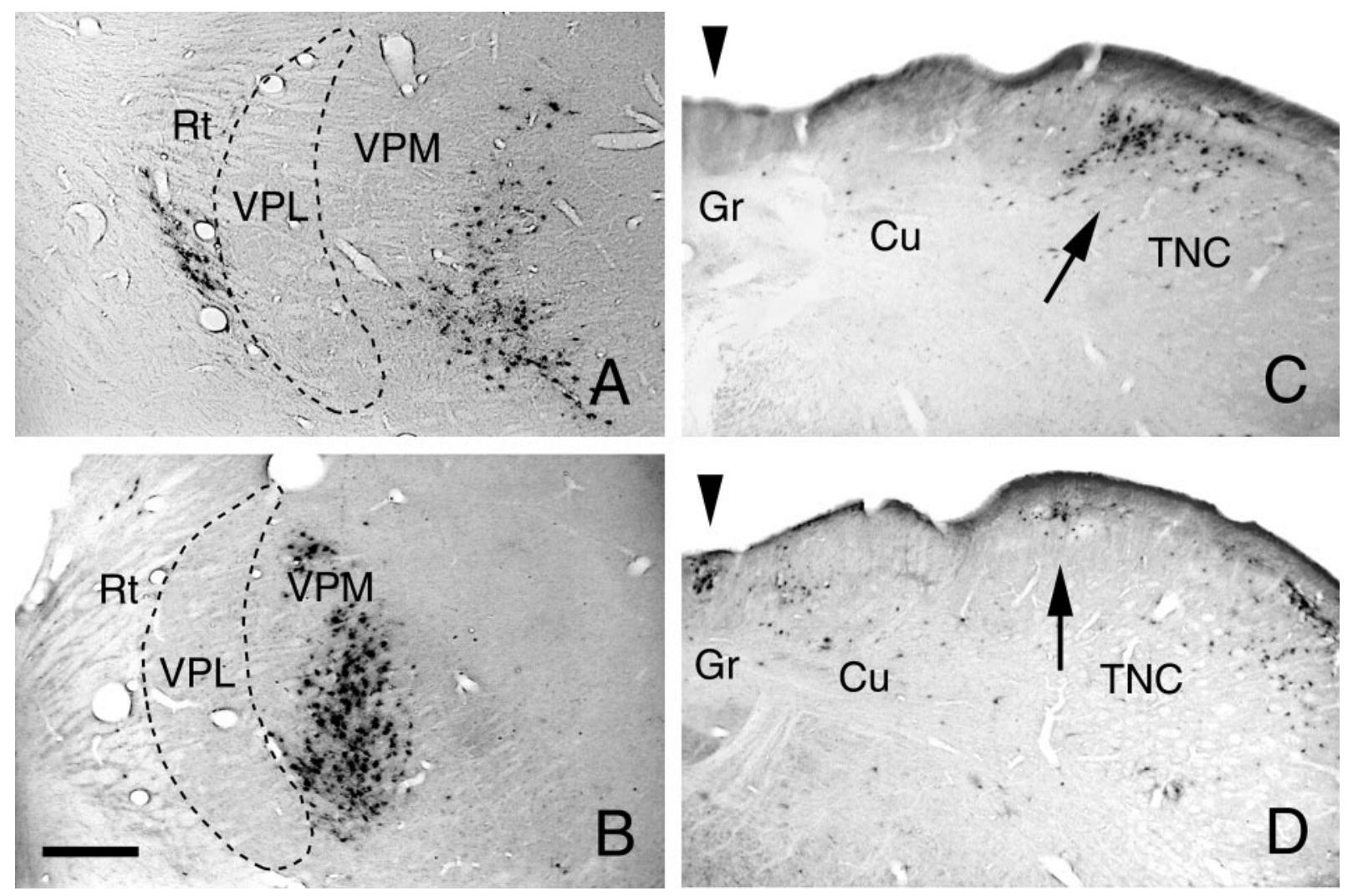

Figure 3. A, Case 92. PRV-immunoreactive neurons at the injection site in the lateral thalamus; the center of the injection site is $520 \mu \mathrm{m}$ from the medial border of the ventroposterolateral nucleus $(V P L)$. The survival time was $72 \mathrm{hr}$. B, Case 89. PRV-immunoreactive neurons at the injection site in the lateral thalamus; the center of the injection site is $320 \mu \mathrm{m}$ from the medial border of the VPL nucleus. The survival time was $77 \mathrm{hr}$. Reticular nucleus of the thalamus $(R t)$; ventroposteromedial nucleus $(V P M)$. $C$, Case 92. Retrogradely labeled PRV neurons in the caudal medulla, at the same level as in Figure $3 C$, are present in the medial trigeminal nucleus caudalis $(T N C)$ only. $D$, Case 89 . Retrogradely labeled PRV-immunoreactive neurons in the caudal medulla are present in both the gracile nucleus ( Gr; arrowhead) and in the medial part of the trigeminal nucleus caudalis (TNC; arrow). Cuneate nucleus (Cu). Scale bar: $300 \mu \mathrm{m}$.

that received a virus injection were confined to a biosafety hood where they were observed every $8 \mathrm{hr}$ for any signs of disease (Pensaert and Kluge, 1989). Virus-injected animals were weighed daily, and their food and water intake were monitored. The animals that demonstrated signs of encephalitis were perfused immediately.

Perfusion. Each animal was anesthetized deeply with a mixture of ketamine $(100 \mathrm{mg} / \mathrm{kg})$ and xylazine $(7 \mathrm{mg} / \mathrm{kg})$ intramuscularly and then perfused through the ascending aorta with $50 \mathrm{ml}$ of $0.05 \mathrm{M}(0.9 \%)$ PBS, followed by $500-1000 \mathrm{ml}$ of $4 \%$ paraformaldehyde in $0.1 \mathrm{M} \mathrm{PBS,} \mathrm{pH} \mathrm{7.4,}$ at room temperature. Two hours later, the spinal cord, brain, and, in cases $51,52,69,70,71,103,104$, and 105 , the trigeminal ganglia were removed and post-fixed in the same fixative solution for $6 \mathrm{hr}$ at $4^{\circ} \mathrm{C}$. The tissues were then cryoprotected in a $30 \%$ solution of phosphate-buffered

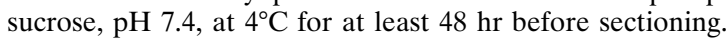

Immunocytochemistry. Fifty micrometer serial transverse sections of the brain and spinal cord and longitudinal sections of the trigeminal ganglia were cut on a freezing microtome. Every fourth section was immunostained.

Sections were floated in a blocking solution made of $3 \%$ normal goat serum (NGS) and $0.3 \%$ Triton X-100 in PBS for $1 \mathrm{hr}$ and then incubated for $48 \mathrm{hr}$ at $4^{\circ} \mathrm{C}$ with a rabbit polyclonal antiserum $(\mathrm{Rb} 134)$ directed against acetone-inactivated PRV (a generous gift from Dr. Lynn Enquist, Princeton University), at a dilution of 1:20,000 in PBS, 1\% NGS, and $0.3 \%$ Triton $\mathrm{X}-100$. After the primary antibody incubation, the tissue was exposed to a goat anti-rabbit biotinylated secondary IgG (Vector Laboratories, Burlingame, CA) diluted 1:200 for $1 \mathrm{hr}$ at room temperature. We used a nickel-diaminobenzidine (nickel-DAB) glucose-oxidase reaction to obtain a black reaction product (Llewellyn-Smith and Minson, 1992). Omission of the primary antibody resulted in the absence of PRV immunoreactivity. For Fluoro-gold immunocytochemisty, the same procedure was followed using a rabbit primary antiserum (a generous gift from Dr. Howard Chang, Memphis, TN) at a dilution of 1:5000. A goat primary antiserum (1:20,000; List Biologic, Campbell, CA) and a biotinylated donkey anti-sheep secondary antiserum (1:200; Sigma, St. Louis, MO) were used for cholera toxin B immunocytochemisty. Horse serum was used for blocking and incubation solutions. Sections were washed three times in Tris buffer, $\mathrm{pH} 7.4$, mounted on gelatin-coated slides, air dried, dehydrated in alcohol in a graded manner, cleared in xylene, and coverslipped.

For double-labeling experiments, cholera toxin B immunocytochemistry using a nickel-DAB reaction was followed by PRV immunocytochemistry as described above, except that nickel was omitted from the DAB solution. These two immunocytochemical procedures resulted in a light brown staining of the PRV-like immunoreactivity that contrasted well with the black cholera toxin immunoreactivity, allowing identification of double-labeled cells over a wide range of staining density for both antigens. Omitting the primary antiserum for cholera toxin or PRV on control sections resulted in the absence of signal for the corresponding antigen. If the PRV immunocytochemistry was performed first, cholera toxin immunocytochemistry failed to show any label. After several controls, we concluded that this artifactual absence of signal was attributable to the binding of the secondary donkey anti-goat with the secondary goat anti-rabbit antibodies. For each antigen, comparison of cell counts made in single- and double-labeled sections from the same animal showed that the double immunocytochemistry did reduce the signal of individual antigens, suggesting that the amount of double-labeled cells might have been underestimated. In an attempt to circumvent this problem, we used a double immunofluorescence protocol in some experiments.

The same primary antibodies were used at higher concentrations (antiPRV, 1:2000; anti-cholera toxin B, 1:10,000) for cholera toxin-PRV immunofluorescence. The secondary antibodies (1:200) were fluorescent goat anti-rabbit conjugated to Texas Red (Amersham, Arlington Heights, IL) and donkey anti-goat conjugated to FITC (Vector) for visualizing PRV and cholera toxin B, respectively. The double-labeling procedure 

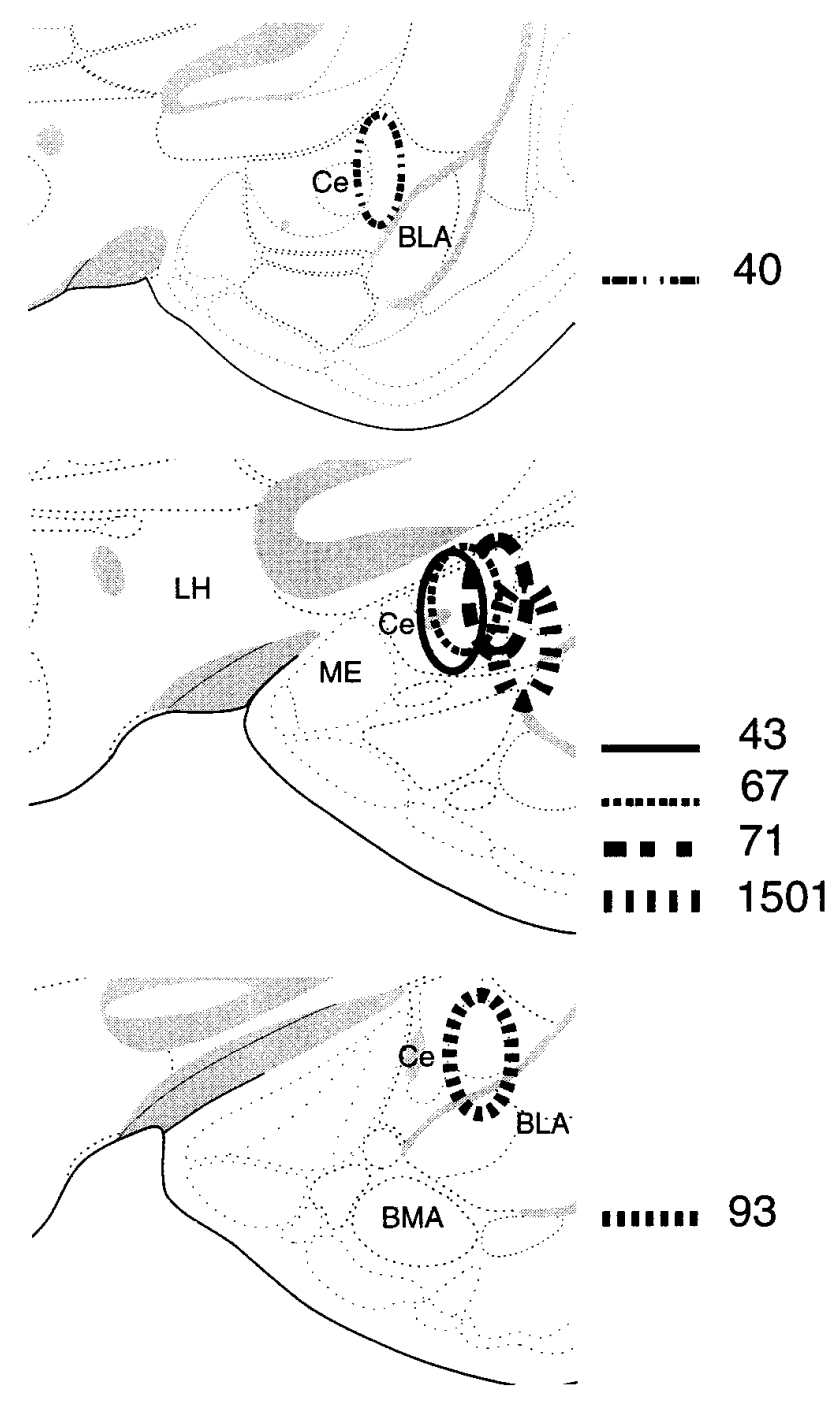

Figure 4. Cases 47, 40, 67, 71, 93. Diagram of PRV and Fluoro-gold injection sites in the amygdala plotted onto section reproduced from the atlas of Swanson (1992). The location of the injection sites was determined from the distribution of gold particles and from the cannula tracts.

involved the same steps as described above, but without a DAB reaction. After the last rinse, the sections were mounted on gelatin-coated slides and air dried, coverslipped with Fluoromount-G (Southern Biotechnology), and stored in the dark at $4^{\circ} \mathrm{C}$. The sections were observed under an epifluorescent microscope with an excitation filter of $510 \sim 560 \mathrm{~nm}$ and a barrier filter of $590 \mathrm{~nm}$ (Texas Red) and with an excitation filter of $470 \sim 490 \mathrm{~nm}$ and a barrier filter of $520 \mathrm{~nm}$ (FITC). Omitting the primary antisera on control sections resulted in the absence of signal for the corresponding antigen.

Photomicrographs. Sections selected for publication were captured on a Power Macintosh (8100/100AV; Apple Computers, Cupertino, CA) with a Nikon Optiphot-2 microscope, and an analog VE-1000 camera and a VC70 Control Unit (Dage-MTI, Michigan, IN) connected to an image capture board (PDI, Redmond, WA). Final images were produced using Adobe Photoshop 3.0.4 (Adobe, Mountain View, CA). Sections from Swanson's atlas (1992) (Fig. 4) were taken from a commercially available software package (Elsevier).

\section{RESULTS}

\section{Defining the spread of the virus at the injection site}

Extracellular PRV immunoreactivity was observed at the site of intracerebral injection only when animals survived less than $24 \mathrm{hr}$
(Fig. 1). At survival times sufficient to obtain retrograde labeling of first-order afferent neurons (26 hr), all PRV immunoreactivity seemed to be confined to cell bodies (Fig. $2 A$ ). These cell bodies were located in the area immediately surrounding the injection site and also at a distance in nuclei with known projections to the injection site. We added $40-\mu \mathrm{m}$-diameter gold particles to the viral suspension to obtain permanent labeling. The latter remain localized to the injection site and are easily identified under dark-field illumination or with transmitted light after silver enhancement (Fig. 2B) (Scopsi and Larsson, 1985). At a concentration of 50:50 $(\mathrm{v} / \mathrm{v})$, retrograde labeling and viral transport were identical to that of animals injected only with the virus, indicating that the gold particles did not block viral replication.

To evaluate the radius of viral diffusion around the pipette tip where uptake of the virus at axonal terminals presumably occurs, cases 85 and 86 received a virus injection in the thalamus or parabrachial area and were perfused at brief survival times (22-76 min, Table 1). On transverse brain sections at the level of the injection site, PRV immunoreactivity was restricted to the deepest portion of the pipette tract (Fig. $1 \mathrm{~A}$, left). The diameter of the immunoreactive area was largest $(200-320 \mu \mathrm{m})$ for animals with the shortest survival (20-27 $\mathrm{min}, n=7)$. Under the same injection conditions, the gold particles diffused over a diameter of $\sim 300$ $\mu \mathrm{m}$. At longer survival times $(66-76 \mathrm{~min}, n=4)$, the PRVimmunoreactive area was smaller $(100-150 \mu \mathrm{m})$ or absent (Fig. $1 A$, right). When present, the immunoreactivity was dense and finely punctate (Fig. $1 B$ ) and, unlike the staining pattern seen at longer survival times $(>26 \mathrm{hr}$ ), it did not delineate cellular profiles, suggesting an extracellular location. This contrasts with the staining pattern at 26-48 hr postinjection, when we recorded many immunoreactive cellular profiles in close proximity and at a distance from the gold particles in a pattern that resembled the retrograde labeling of first-order afferents using Fluoro-gold (see below) (Fig. 2A). At survival times greater than $48 \mathrm{hr}$, PRV immunoreactivity was often not detectable in the vicinity of the injection site, presumably attributable to clearance of the virusinfected cells by the immune response (Fig. 2B) (Card and Enquist, 1995).

PRV was injected in the VPM, and retrograde labeling was examined in the caudal medulla to evaluate the radius of viral uptake. Cases 89 and 92 illustrate the results of these experiments. In case 92 , the center of the injection site was located $520 \mu \mathrm{m}$ from the medial border of the VPL (Fig. $3 A$ ). In case 89, the injection site was $320 \mu \mathrm{m}$ medial to the VPL (Fig. 3B). Labeling in the caudal medulla was predominantly located in the TNC for both cases (Fig. 3C,D). There was, however, a striking difference between the two cases in the number of PRV-labeled neurons in the dorsal column nuclei. In case 92, there was only an occasional labeled dorsal column neuron, whereas in case 89, there were many (Fig. 3C,D, arrowhead). In another experiment, cholera toxin B was coinjected with PRV in the VPM; the center of the injection was $550 \mu \mathrm{m}$ from the medial border of the VPL. The diameter of the PRV immunolabeling at the injection site was 140 $\mu \mathrm{m}$, whereas that of CTB was $1000 \mu \mathrm{m}$. In these animals, PRVand cholera-toxin-immunoreactive neurons were found in the trigeminal nucleus caudalis, but only cholera-toxin-labeled neurons were recorded in the dorsal column nuclei. The results of these experiments suggest that when $100 \mathrm{nl}$ of a $1 \times 10^{8} \mathrm{pfu}$ concentration per $\mathrm{ml}$ of $\mathrm{PRV}$ is microinjected into the brain parenchyma, viral uptake occurs up to $\sim 520 \mu \mathrm{m}$ radially around the pipette tip. These experiments also indicate that there is less diffusion of PRV than cholera toxin B. 

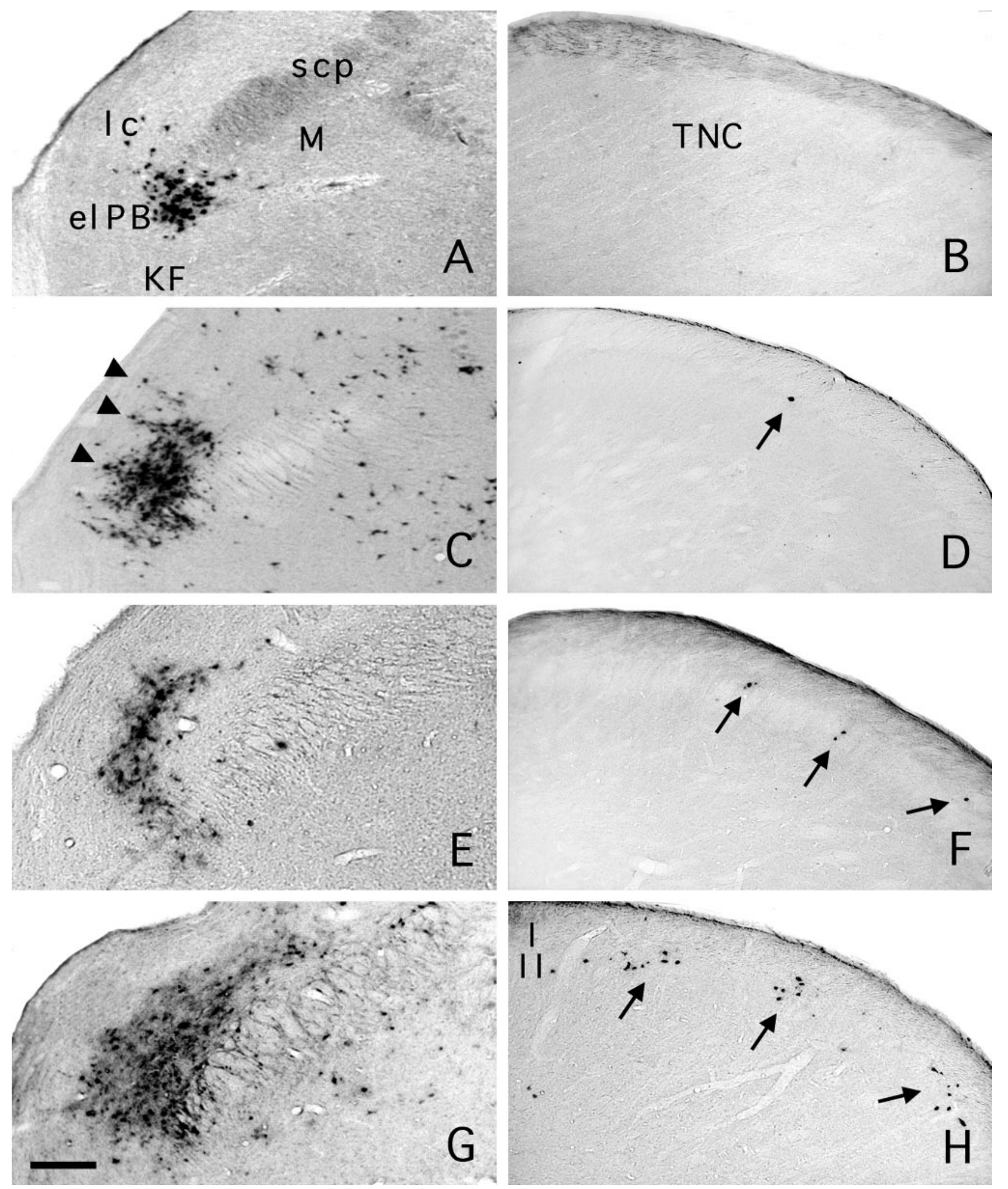

Figure 5. PRV immunoreactivity in the ipsilateral parabrachial area and caudal medulla after PRV injection in the Ce. Case 47. A, Parabrachial area $26 \mathrm{hr}$ after injection in the Ce (see Fig. 4). The retrogradely labeled neurons were largely restricted to the elPB. $B$, There is no labeling in the trigeminal nucleus caudalis $(T N C) 26 \mathrm{hr}$ after PRV injection in the Ce. Case 40. C, PRV immunoreactivity in the ipsilateral parabrachial area 46 hr after injection in the Ce. Cusp-shaped islets formed of PRV-labeled cell bodies (arrowheads) extend into the lateral crescent area from the el PB. D, With this survival time, we found very few PRV-immunoreactive neurons in lamina I of the ipsilateral caudal medulla (arrow). Case 93. E, PRV immunoreactivity in the ipsilateral parabrachial area $52 \mathrm{hr}$ after injection in the Ce. F, PRV-immunoreactive neurons were observed at somewhat regular intervals in lamina I of the trigeminal nucleus caudalis (arrows). Occasionally we found two adjacent cells that spanned the dorsoventral extent of lamina I. Case 71. $G$, PRV immunoreactivity in the ipsilateral parabrachial area $76 \mathrm{hr}$ after injection in the Ce. $H$, In the ipsilateral caudal medulla, we recorded clusters of PRV-immunopositive neurons that included neurons in lamina I and in the ventrally subjacent lamina II. As for $F$, the clusters were located at somewhat regular intervals. External lateral nucleus $(e l P B)$; Kölliker-Fuse $(K F)$; lateral crescent area $(l c)$; medial nucleus $(M)$; superior cerebellar peduncle $(s c p)$. Scale bar: $150 \mu \mathrm{m}$. 

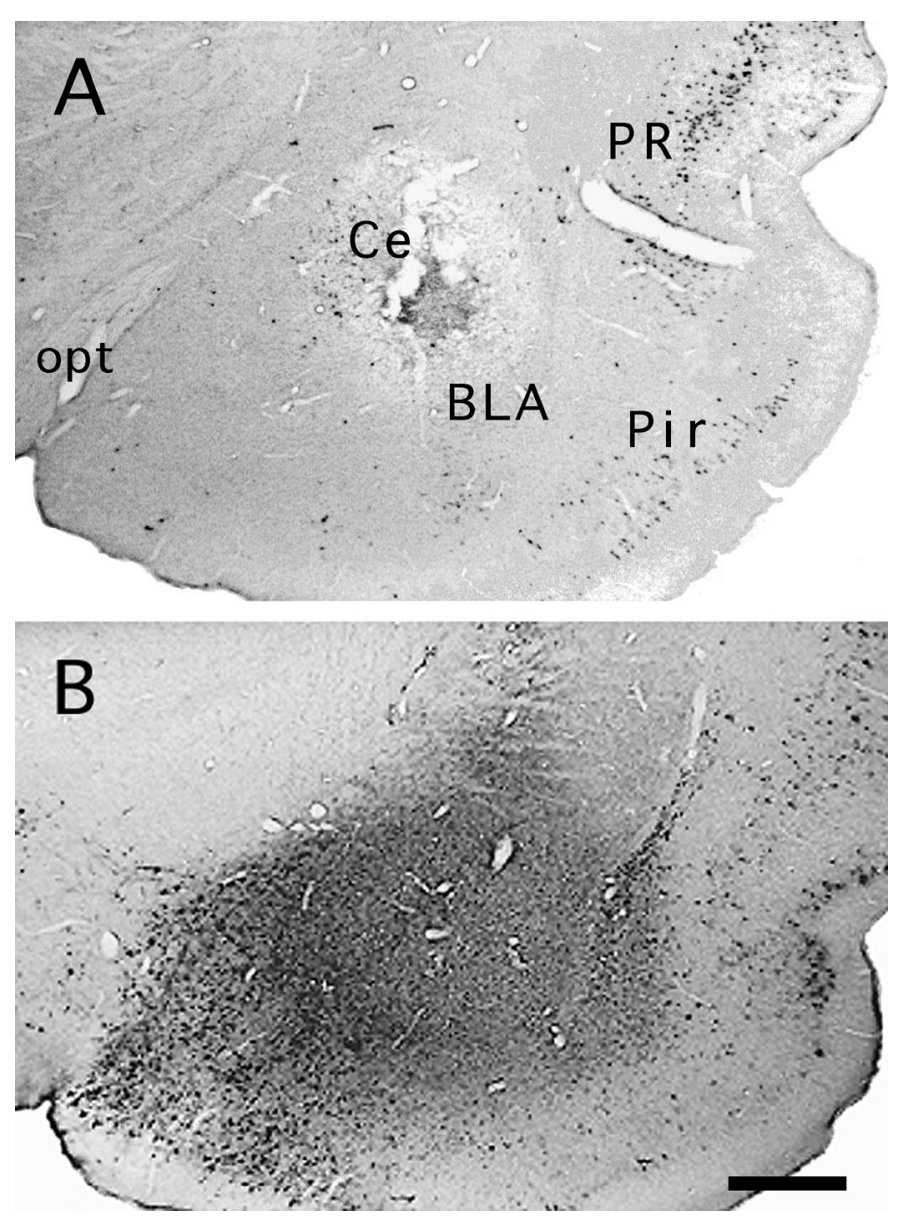

Figure 6. Case 71. Characteristics of injection site after coinjection of PRV and Fluoro-gold. Immunostaining for PRV $(A)$ shows the cannula tract and a small area of tissue necrosis. The center of injection is at the junction of the lateral Ce and the basolateral nucleus $(B L A)$. Note that the injection site is almost devoid of PRV immunoreactivity. The perirhinal $(P R)$ and piriform cortex (Pir), however, contain retrogradely labeled neurons. An adjacent section immunostained for Fluoro-gold $(B)$ demonstrates the much greater radius of diffusion and the consequent more extensive retrograde labeling of neurons that project to the amygdala (see Table 2). Optic tract (opt). Scale bar: $500 \mu \mathrm{m}$.

\section{Amygdala injections}

Sixteen rats were injected in the right amygdala with PRV and gold particles or for some animals, with PRV and cholera toxin B or Fluoro-gold. Cases 47, 40, 93, and 71 will be presented as representative cases. These rats were perfused $26,46,52$, and 76 $\mathrm{hr}$, respectively, after virus injection to assess progression of the virus in the spino-(trigemino-)parabrachial pathway.

In case 47, $200 \mathrm{nl}$ of PRV was injected in the Ce (Fig. 4), and the animal was perfused $26 \mathrm{hr}$ later. PRV immunolabeling in the pons was discrete and limited to the ventrolateral parabrachial area bilaterally (Fig. 5A, Table 2). No labeled cells were present in the trigeminal nucleus caudalis, and a only few cells were seen in the ipsilateral nucleus of the solitary tract and the adjacent medial reticular formation (Fig. $5 B$, Table 2 ). In case 40 , a larger volume $(300 \mathrm{nl})$ was injected in the center of the Ce (Fig. 4), and the animal was perfused after $48 \mathrm{hr}$. In the pons, there was abundant retrograde labeling in the elPB, and scattered labeling was found in other divisions of the parabrachial complex (Table 1, Fig. 5C). In the trigeminal nucleus caudalis, isolated PRV-labeled neurons were found in the dorsomedial portion of lamina I (Fig. 5D). We found no labeled cells in the spinal cord in either case. In case 93, the injection was localized to the lateral division of the Ce (Figs. $2 B, 4)$. This injection resulted in retrograde labeling of a limited number of brainstem areas (Table 2). In the pons, most labeled cells were found in the elPB with an ipsilateral predominance (Fig. 5E). In the trigeminal nucleus caudalis, PRV-labeling was sparse bilaterally but more widespread than for case 40 , being found throughout lamina I at regular intervals (at 230-460 $\mu \mathrm{m}$ ), with a few cells in lamina $\mathrm{V}$ and the adjacent medial reticular area (Table 1, Fig. 5F). The dorsomedial portion of the superficial dorsal horn of the nucleus caudalis was an exception. It often contained small groups (up to 10 per section) of PRV-labeled cells. In this rat, we did not detect PRV immunoreactivity in the trigeminal ganglia.

In case 71, $50 \mathrm{nl}$ of PRV was injected in the Ce 1 week after 40 nl of Fluoro-gold using the identical coordinates. Although we did not detect PRV immunoreactivity at the injection site (Fig. 6 A ), we recorded dense Fluoro-gold immunolabeling extending to all divisions of the central and basal nuclei, as well as to the medial nucleus, the amygdalostriatal junction, and the dorsal endopiriform nucleus (Fig. 6B). In the parabrachial area, PRV-Fluorogold double-labeled neurons were concentrated in the elPB bilat-

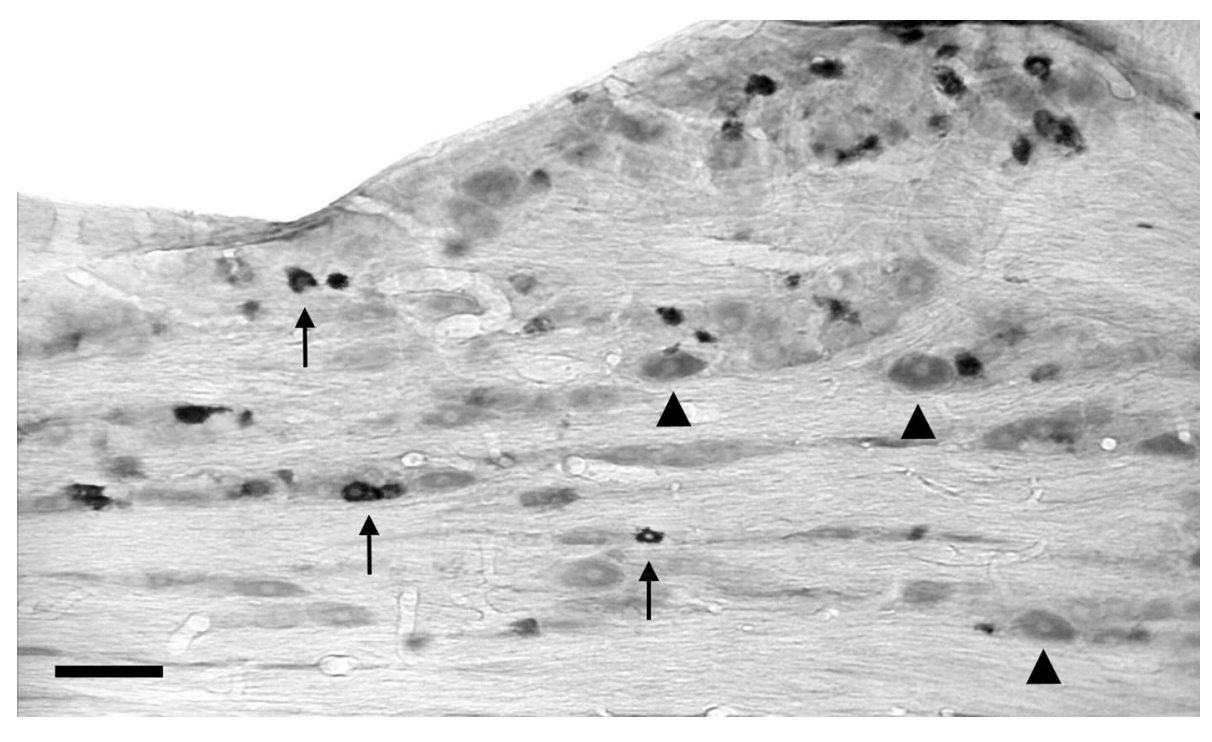

Figure 7. Case 71. PRV immunoreactive neurons in the trigeminal ganglion ipsilateral to the Ce injection. Labeled cells (arrows) demonstrate a dark reaction product; most of these are of small diameter. By contrast, unlabeled cells (arrowheads), visible because of light background staining, are larger. Scale bar: $100 \mu \mathrm{m}$. 
Table 2. Retrograde labeling

\begin{tabular}{|c|c|c|c|c|c|c|c|c|c|}
\hline & \multicolumn{6}{|c|}{ PRV injections in the $\mathrm{Ce}$} & \multicolumn{3}{|c|}{ PRV injections in the elPB } \\
\hline & $\begin{array}{l}\text { PRV } \\
47 \text { PRV } \\
\text { ipsi/ } \\
\text { contra }\end{array}$ & $\begin{array}{l}\text { Case } \\
40 \mathrm{PRV} \\
\text { ipsi/ } \\
\text { contra }\end{array}$ & $\begin{array}{l}\text { Case } \\
93 \mathrm{PRV} \\
\text { ipsi/ } \\
\text { contra }\end{array}$ & $\begin{array}{l}\text { Case } \\
71 \mathrm{PRV} \\
\text { ipsi/ } \\
\text { contra }\end{array}$ & $\begin{array}{l}\text { Case } \\
71 \mathrm{FG} \\
\text { ispi/ } \\
\text { contra }\end{array}$ & $\begin{array}{l}\text { Case } \\
67 \mathrm{FG} \\
\text { ipsi/ } \\
\text { contra }\end{array}$ & $\begin{array}{l}\text { Case } \\
103 \text { PRV } \\
\text { ipsi/ } \\
\text { contra }\end{array}$ & $\begin{array}{l}\text { Case } \\
51 \mathrm{PRV} \\
\text { ipsi/ } \\
\text { contra }\end{array}$ & $\begin{array}{l}\text { Case } \\
51 \text { CTB } \\
\text { ipsi/ } \\
\text { contra }\end{array}$ \\
\hline \multicolumn{10}{|l|}{ PONS } \\
\hline \multicolumn{10}{|l|}{ Parabrachial subnuclei } \\
\hline Central lateral & $0 / 0$ & $+/-$ & $+/+$ & $+/+$ & $+/+$ & $+/+$ & & & \\
\hline Dorsal lateral & $0 / 0$ & $0 / 0$ & $0 / 0$ & $0 / 0$ & $0 / 0$ & $+/+$ & & & \\
\hline External lateral & $+/+$ & $++/+$ & $++/+$ & $+++/+++$ & $+++/++$ & $+++/++$ & & & \\
\hline External medial & $++/+$ & $+/+$ & $+/+$ & $+/+$ & $++/+$ & $+/+$ & & & \\
\hline Internal lateral (il) & $0 / 0$ & $0 / 0$ & $0 / 0$ & $+/+$ & $0 / 0$ & $0 / 0$ & & & \\
\hline Kölliker-Fuse (kf) & $0 / 0$ & $0 / 0$ & $0 / 0$ & $0 / 0$ & $0 / 0$ & $0 / 0$ & & & \\
\hline Lateral crescent area (lc) & $0 / 0$ & $0 / 0$ & $0 / 0$ & $0 / 0$ & $0 / 0$ & $+/ 0$ & & & \\
\hline Medial (m) & $0 / 0$ & $+/+$ & $+/+$ & $+/+$ & $+++/+$ & $+/ 0$ & & & \\
\hline Superior lateral (sl) & $0 / 0$ & $0 / 0$ & $0 / 0$ & $0 / 0$ & $0 / 0$ & $0 / 0$ & & & \\
\hline Ventral lateral (vl) & $0 / 0$ & $+/+$ & $+/+$ & $+/+$ & $+++/+$ & $++/+$ & & & \\
\hline Waist (w) & $0 / 0$ & $+/ 0$ & $+/ 0$ & $+/+$ & $+++/+$ & $++/+$ & & & \\
\hline \multicolumn{10}{|l|}{ CAUDAL MEDULLA } \\
\hline A1 region & $0 / 0$ & $++/+$ & $+/+$ & $++/++$ & $++/+$ & $+/+$ & $++/++$ & $++/++$ & $++/++$ \\
\hline N. Solitary tract & $+/ 0$ & $++/+$ & $+/-$ & $++/++$ & $++/ 0$ & $+/ 0$ & $+++/++$ & $+++/++$ & $+++/++$ \\
\hline \multicolumn{10}{|l|}{$\begin{array}{c}\text { Trigeminal subnucleus } \\
\text { caudalis }(\mathrm{Sp} \mathrm{Vc})\end{array}$} \\
\hline Lamina I & $0 / 0$ & $+/+$ & $+/+$ & $++/++$ & $0 / 0$ & $0 / 0$ & $+++/++$ & $+++/+++$ & $++/+++$ \\
\hline Lamina II & $0 / 0$ & $0 / 0$ & $0 / 0$ & $++/++$ & $0 / 0$ & $0 / 0$ & $++/+$ & $+++/+++$ & $+/+$ \\
\hline Lamina III-IV & $0 / 0$ & $0 / 0$ & $0 / 0$ & $0 / 0$ & $0 / 0$ & $0 / 0$ & $0 / 0$ & $+/+$ & $+/+$ \\
\hline Lamina V & $0 / 0$ & $0 / 0$ & $+/ 0$ & $+/ 0$ & $0 / 0$ & $0 / 0$ & $0 / 0$ & $++/+$ & $++/++$ \\
\hline Paratrigeminal nucleus & $0 / 0$ & $0 / 0$ & $+/+$ & $++/++$ & $0 / 0$ & $0 / 0$ & & & \\
\hline \multicolumn{10}{|l|}{ SPINAL CORD } \\
\hline \multicolumn{10}{|l|}{ Cervical } \\
\hline Lamina I & $0 / 0$ & $0 / 0$ & $+1-$ & $++/++$ & $0 / 0$ & $0 / 0$ & $++/+$ & $++/+++$ & $+/+++$ \\
\hline Lamina II & $0 / 0$ & $0 / 0$ & $0 / 0$ & $+/+$ & $0 / 0$ & $0 / 0$ & $+/ 0$ & $++/+++$ & $0 / 0$ \\
\hline Lateral spinal nucleus & $0 / 0$ & $0 / 0$ & $0 / 0$ & $+/+$ & $+/+$ & $0 / 0$ & $+/+$ & $++/++$ & $++/++$ \\
\hline Reticular formation & & & & & & & & & \\
\hline of neck & $0 / 0$ & $0 / 0$ & $0 / 0$ & rare/rare & $+/+$ & $0 / 0$ & $+/+$ & $+/+$ & $++/++$ \\
\hline
\end{tabular}

erally (Fig. 5G). Neurons labeled with Fluoro-gold only were also abundant in other divisions of the parabrachial complex (Table 2). In the caudal medulla, only PRV-labeled neurons were observed in the nucleus caudalis (Fig. $5 H$ ); both PRV and Fluoro-gold neurons were present in the A1 region and in the nucleus of the solitary tract. Compared with case 93 (above), the longer time allowed for viral transport resulted in transneuronal labeling of neurons of lamina II of the nucleus caudalis, as well as for additional labeling of neurons in the paratrigeminal nucleus and reticular formation (Table 2). In laminae I and II, the PRVimmunolabeled neurons were distributed equally on both sides of the midline and were arranged in radially oriented columns (Fig. $5 H)$. The spacing between these columns ranged from 230 to 460 $\mu \mathrm{m}$. At high magnification, many of these cells had neuronal profiles with visible proximal dendritic processes. In lamina $\mathrm{V}$, labeling was infrequent and ipsilateral to the injection site, as in case 93. In the spinal cord, at the level of the cervical enlargement, most of the PRV-labeled cells were located in the superficial dorsal horn. In lamina I, the labeled cells either formed small clusters or existed singly and in isolation. When present in lamina II, PRV-immunolabeled cells lay immediately ventral to the labeled lamina I cells, forming radially oriented columns through the superficial dorsal horn comparable to the pattern described above for the trigeminal nucleus caudalis. Labeled cells were also seen in the reticulated area of the neck of the dorsal horn (lamina $\mathrm{V})$ and in the adjacent white matter.

In this case, we immunostained the trigeminal ganglia for PRV alone (Fig. 7) and used a double immunofluorescence procedure to identify neurons double stained for PRV and substance P (Fig. $8 A$ ). Of 936 ganglion neurons examined, 112 (12\%) were immunopositive for PRV, 206 (22\%) for substance P, and 84 (9\%) were for both PRV and substance P.

\section{Effect of bilateral elPB lesions}

The excitotoxin ibotenic acid was injected into the elPB bilaterally 1 week before PRV with colloidal gold in the Ce in three animals (1501, 1508, and 1510). In all three cases silver intensification of the colloidal gold coinjected with the virus confirmed PRV injection in the lateral portion of the Ce (Fig. 4). All three rats survived longer than $72 \mathrm{hr}$ (Table 1), at which time PRV immunoreactivity is normally present throughout the superficial laminae of the TNC and the spinal dorsal horn (case 71, Fig. $5 H$ ). Case 1501 will be described as representative. In this animal, symmetrical lesions of the lateral parabrachial area were evident on both Nissl-stained and PRV-immunoreacted tissue (Fig. 9A-C). Many immunopositive cell bodies were present in most divisions of the parabrachial 

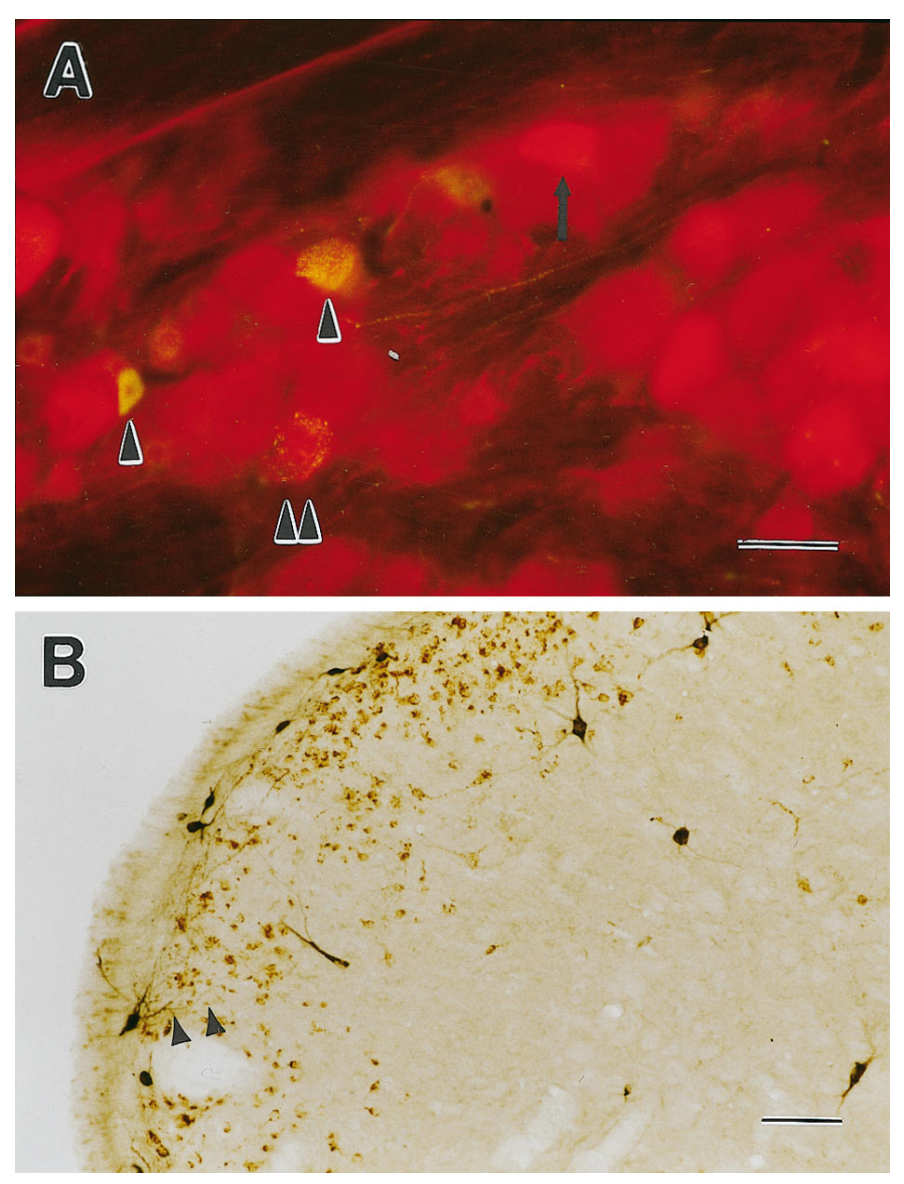

Figure 8. A, Case 71. High magnification of trigeminal ganglion on the side of PRV injection in the Ce. The tissue has been double labeled for PRV (red immunofluorescence) and the neurotransmitter substance P (yellow immunofluorescence). Two cells labeled exclusively for substance $\mathrm{P}$ are evident (single arrowhead), as well as one for PRV only (arrow). One example of a double-labeled cell is indicated by a double arrowhead. The light red cytoplasmic fluorescence of many large cells is background signal only. $B$, Case 101. Trigeminal nucleus caudalis double labeled for PRV injected in the $\mathrm{Ce}$ (brown reaction product) and cholera toxin injected in the elPB (black reaction product). Cholera-toxin-labeled neurons are present mostly in lamina I, with a few in laminae III, IV, and V. PRV labeling is confluent in lamina I and II consistent with the longer time post-injection ( $96 \mathrm{hr}$ ). All cholera toxin-labeled cells were double labeled for PRV, similar to case 51, for which the two tracers were injected in the parabrachial (Fig. 12). More importantly, the dendritic profiles of choleratoxin-labeled lamina I parabrachial projection cells are seen to extend into lamina II (arrowheads). Scale bars: $A, 50 \mu \mathrm{m} ; B, 100 \mu \mathrm{m}$.

complex, with the striking exception of the elPB and immediately adjacent tissue (Fig. 9C). A paucity of PRV-immunopositive cells were found in lamina I of the TNC (Fig. 9D), although expected labeling was obtained in the nucleus of the solitary tract and in the reticular formation at this survival time. In the spinal cord, occasional PRV immunopositive neurons were found in lamina I of the dorsal horn bilaterally. More consistently labeled neurons were located around the central canal, in the lateral spinal nucleus, and in the reticulated area of the dorsal horn (lateral portion of lamina $\mathrm{V}$ ).

\section{Comparison of the labeling after PRV or Fluoro-gold injection}

We made injections of Fluoro-gold in the $\mathrm{Ce}$ in four animals and compared the pattern of labeling with that found after PRV injection. These injections without PRV were necessary because the small volumes required to obtain a restricted Fluoro-gold injection site $(\leq 40 \mathrm{nl})$ are incompatible with adequate PRV uptake and transport. In fact, volumes $<50 \mathrm{nl}$ of PRV could not be used because injection of less than $5 \times 10^{3}$ virions $(50 \mathrm{nl}$ of a $1 \times 10^{8} \mathrm{pfu} / \mathrm{ml}$ solution) was associated with either the absence of replication of the virus or a prolonged and less predictable time course of viral replication and transneuronal passage. Case 67 will be used to make these comparisons because the location and size of the Fluoro-gold $(40 \mathrm{nl})$ injection site is similar to that of case 71 , which received PRV. The injection included all of the Ce, with the exception of its rostral pole, and it encroached on the adjacent mediodorsal portion of the lateral and basolateral amygdaloid nuclei, the intra-amygdaloid bed nucleus of the stria terminalis, and the ventral portion of the amygdalostriatal transition area (Fig. 4). In the parabrachial area (Fig. 10), the retrogradely labeled cells were concentrated in the elPB; this is comparable to case PRV-71 (Table 2). Compared with PRV or PRV with Fluoro-gold, Fluoro-gold alone provided better labeling of the dendrites of elPB neurons. These dendrites extended radially into the more lateral parabrachial nuclei: the superior lateral, the lateral crescent $(l c)$, and the Kölliker-Fuse $(K F)$ (Fig. 10). As we noted after PRV injection in the Ce (Fig. $5 C$ ), Fluoro-gold injections resulted in labeling of cusp-shaped clusters of cells that extended from the elPB into the lc (Fig. 10, arrowheads). To our knowledge, these islets of Ce-projecting cells have not been described previously. Finally, in the spinal cord, we recorded a few Fluoro-gold-labeled cells, mostly contralateral to the injection site, in deep laminae of the dorsal horn, near the central canal, and in the lateral spinal nucleus, confirming a previous report (Menétrey and de Pommery, 1991). Only rarely did we find Fluoro-gold-labeled neurons in lamina I.

\section{Parabrachial injections}

We made PRV injections into the right parabrachial complex with either cholera toxin B or gold particles in six rats (Table 1). The survival period ranged from 56 to $96 \mathrm{hr}$. The injections were made in the ventrolateral area of the parabrachial complex, encompassing the elPB and adjacent lc nucleus (Fig. 11 $A$ ). The purpose of these experiments was to determine whether the pattern of retrograde labeling produced in the caudal medulla and spinal cord was similar to that obtained by injection in the $\mathrm{Ce}$, which would provide further evidence that PRV was relayed transneuronally from the Ce to the caudal medulla and spinal cord via the lateral parabrachial complex. The distribution of PRV-labeled cells in the caudal medulla and spinal cord will be described for two cases in which different times were allowed for viral transport.

Case 103 was perfused $56 \mathrm{hr}$ after injection $80 \mathrm{nl}$ of PRV. In the trigeminal nucleus caudalis, we recorded isolated neurons or groups of two to eight labeled neurons in lamina I (Table 2, Fig. $11 B)$. These clusters were separated from each other by 130-360 $\mu \mathrm{m}$. The largest number of infected cells was found in the dorsomedial area of lamina I, bilaterally (Fig. $11 \mathrm{~B}$, arrowheads). This result is similar to that seen after injection of PRV in the amygdala (case 93, above). The narrower interval between columns after elPB injections suggests that more columns could be projecting to the elPB than are relayed to the Ce. The pattern of labeling in lamina II resembled another case injected in the amygdala (case 71 above). Clusters of labeled cells extending radially toward the deeper layers were almost always aligned with the labeled cells in lamina I. These radially oriented columns were formed of 2 (20 $\mu \mathrm{m}$ width) to 10 radially oriented neurons (160 

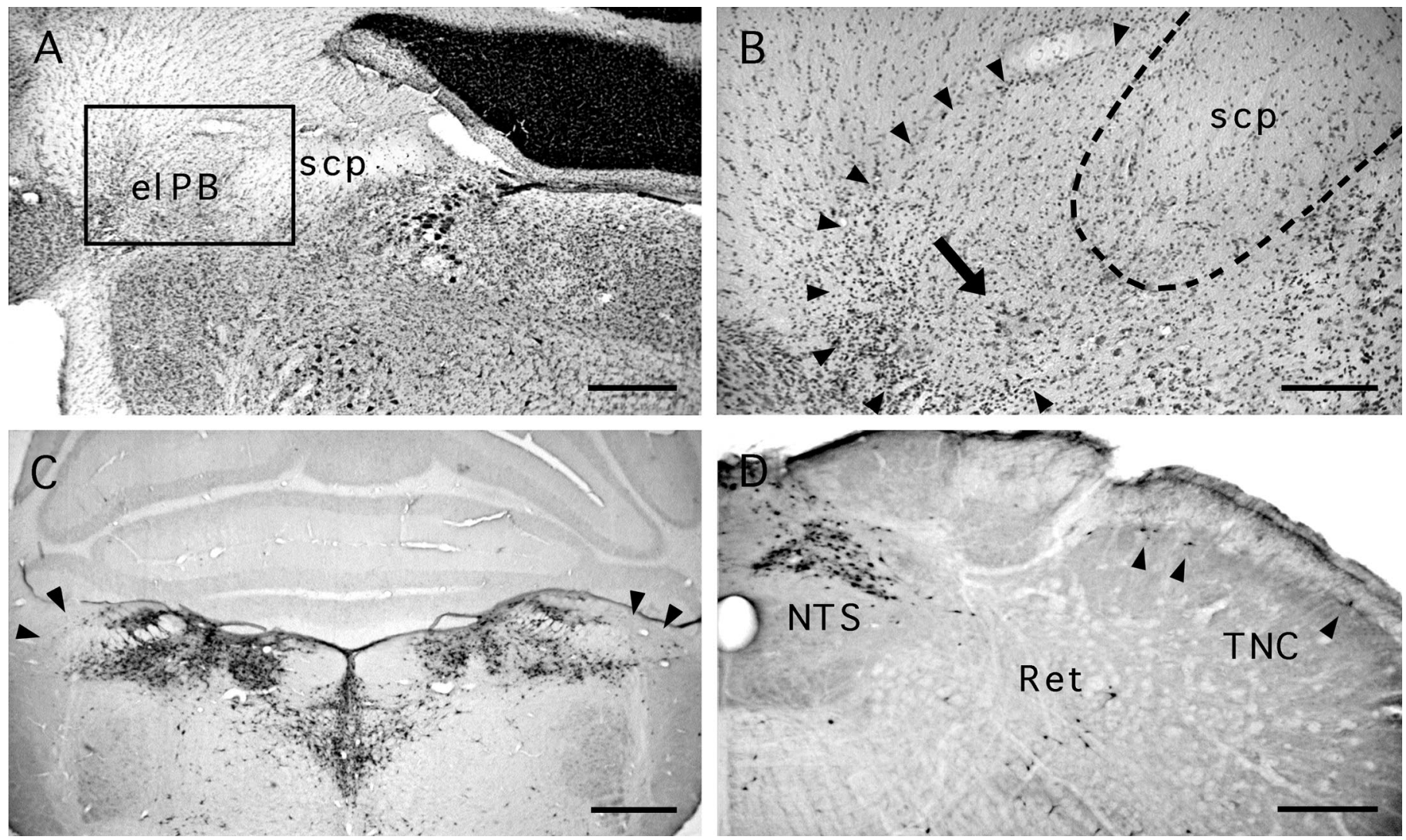

Figure 9. Case 1501. $A, B$, Low- and high-power views of a Nissl-stained section through an ibotenic acid lesion in the lateral parabrachial. Disruption of the cellular architecture in the elPB and vicinity (boxed area in $A$ ) is evident at high magnification $(B)$. Arrowheads delimit the lesioned area in which normal appearing perikarya are no longer recognized. The arrow points to a cluster of pyknotic perikarya within the lesion. The interrupted line delineates the superior cerebellar peduncle $(s c p)$. $C, D, \mathrm{PRV}$ immunoreactivity. $C$, In the pons, the parabrachial area is filled with immunopositive neurons, with the exception of the region of the elPB (arrows). In the caudal medulla, abundant labeling is observed in the nucleus of the solitary tract (NTS), whereas moderate labeling is present in the reticular formation (Ret). Several immunopositive cells (arrowheads) are present in lamina I of the trigeminal nucleus caudalis (TNC). Scale bars: $A, C, D, 500 \mu \mathrm{m} ; B, 200 \mu \mathrm{m}$

$\mu \mathrm{m}$ width). An identical pattern of labeling was observed in the superficial dorsal horn of the cervical cord (Fig. 11C).

In case 51 , we coinjected $200 \mathrm{nl}$ of PRV with $1 \%$ cholera toxin $\mathrm{B}$ in the lateral parabrachial area; $96 \mathrm{hr}$ were allowed for viral transport. In the caudal medulla, PRV-labeled neurons densely populated laminae I and II of the dorsal horn on both sides of the midline; cholera toxin B-labeled neurons were concentrated to lamina I with a slight contralateral predominance (60\%) (Table 2, Fig. $12 A, B)$. At high magnification, it could be seen that the majority of the cholera toxin B-labeled neurons were double labeled for PRV (Fig. 12B). The distribution of PRV neurons in nucleus caudalis was denser, which masked the columnar pattern described above, presumably because of the confluence of adjacent clusters of neurons at this longer period postinjection (Fig. $12 A)$. In the spinal cord, we found densely labeled PRV-labeled cell columns in laminae I and II on all sections, both at cervical and lumbar levels (Table 2, Fig. 12C,D). There too, cholera toxin B-labeled neurons were largely confined to lamina I and most of them $(70-80 \%)$ were double labeled for PRV. At both the medullary and spinal levels, some PRV columns failed to align with cholera toxin B lamina I cells, presumably because an immune response cleared some of the cholera toxin B-PRV doublelabeled neurons.

A similar pattern of labeling in lamina I and II of the nucleus caudalis and spinal dorsal horn was seen in case 101 after PRV injection in the $\mathrm{Ce}$ and cholera toxin $\mathrm{B}$ in the elPB. Extensive PRV-labeling of laminae I and II of the TNC (Fig. 8B) was produced. As expected, most cholera toxin-labeled parabrachial projection neurons were seen in lamina I and were double labeled for PRV. Significantly, cholera toxin revealed that these lamina I parabrachial projection neurons had extensive dendritic arborizations in lamina II (Fig. 8B, arrowheads). Because PRV is transmitted in a retrograde manner, these dendrites could provide a route of passage for the virus from lamina I to lamina II.

Finally, for all cases of injection in the parabrachial complex, retrograde labeling was present in the amygdala, confirming the reciprocal projections that have been described previously (Krettek and Price, 1978). In the ipsilateral amygdala, at survivals of 72 hr and less, PRV labeling was found in the Ce, with sparse to moderate labeling in the amygdalostriatal transition area (Fig. $11 D$ ), the posterior basomedial nucleus, and the anterior and posterior basolateral nuclei. Few labeled cells were seen in the same areas in the contralateral amygdala. At longer survival times, PRV labeling extended to most of the subdivisions of the ipsilateral amygdala, presumably because of the dense interconnections between subnuclei (Amaral et al., 1992; Smith and Paré, 1994; Pitkänen et al., 1995; Savander et al., 1995). In the contralateral amygdala, abundant labeling was seen in the medial nucleus and the ventral part of the basolateral nucleus. A few labeled neurons 


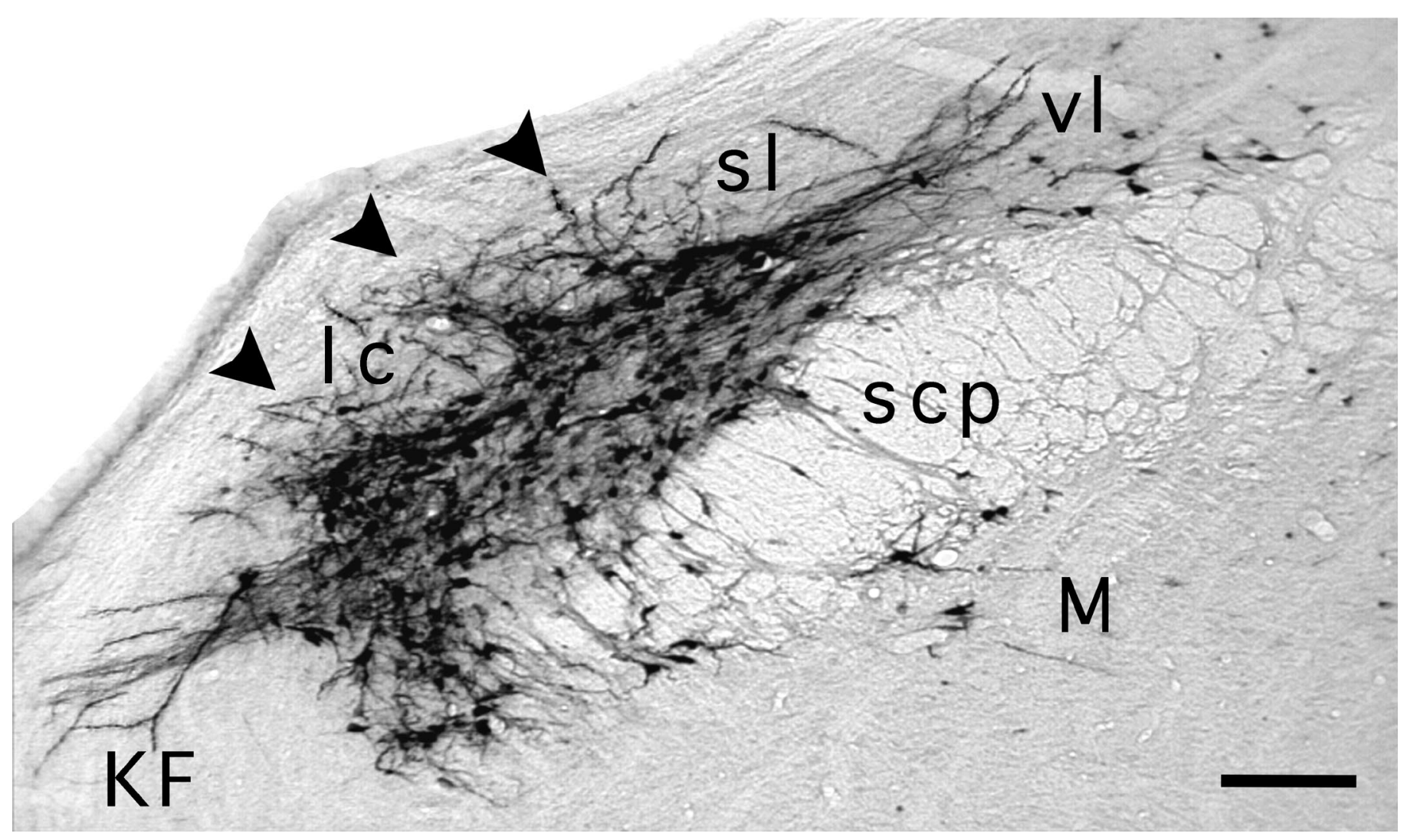

Figure 10. Case 67. Retrograde labeling with Fluoro-gold in the parabrachial complex after injection in the Ce (for injection site, see Fig. 4). Dense labeling is present in the elPB (not labeled for clarity); isolated cell bodies are present in the medial $(M)$ and ventral lateral ( $v l$ ) subnuclei. Two striking features characterize the pattern of labeling in the elPB. First, as we found after retrograde PRV labeling from the amygdala, cusp-shaped islets formed of cell bodies (arrowheads) extend into the lateral crescent area $(l c)$ from the elPB. Second, long dendrites extend from the elPB neurons and islets into the lc, the Kölliker-Fuse $(K F)$, and the superior lateral subnucleus $(s l)$. Scale bar: $120 \mu \mathrm{m}$.

were seen in the $\mathrm{Ce}$ and in the posteromedial cortical amygdaloid nucleus.

\section{DISCUSSION}

As in all studies using retrograde tracers, a critical issue concerns the area of the injection site from which uptake and transport of the tracer occurs. Lysis of neurons at the injection site by PRV makes their subsequent identification difficult; thus, colloidal gold was used to identify the injection site at long survival periods, but colloidal gold in itself does not directly indicate the area of viral uptake. We therefore performed a series of studies that examined the size of the injection site as a function of survival time and locus of uptake inferred from retrograde labeling. Our results demonstrate a restricted diffusion and uptake of the virus around the injection site. A well delimited area of extracellular PRV immunoreactivity was detected immediately after injection, and sitespecific retrograde labeling was found in the brainstem after injection in the somatosensory thalamus.

Factors that may contribute to the limited diffusion of PRV immunoreactivity after direct injection in the brain include the ubiquitous extracellular proteoglycans (Fuxe et al., 1994) to which herpesvirus adheres (Karger et al., 1995). Once injected, the virus particles would not persist in the extracellular space but would enter cells by fusion of the viral membrane with the axon terminal and perikaryon cytoplasmic membrane (Marchand and Schwab, 1986; Card and Enquist, 1995). In neurons, the virus is retrogradely transported to the nucleus of the cell, losing its tegument and capsid (Roizman and Furlong, 1974; Spear, 1993; Card and
Enquist, 1995). Because the antiserum used to detect PRV is directed against the entire virus particle, we propose that disassembly of PRV particles and subsequent modification of the viral proteins is responsible for the loss of PRV immunoreactivity after intracerebral injection. Reappearance of PRV immunoreactivity in first-order neurons occurs after an interval long enough for viral retrograde transport and replication to occur with the resultant expression of new viral proteins (Card and Enquist, 1995). Neurons immunolabeled 24-36 hr after injection, therefore, have direct axonal projections to the injection site, whether their cell body is in the vicinity of the injection site or at a distance, such as in the brainstem, after injection in the amygdala. At $>48 \mathrm{hr}$ postinjection, these populations were no longer identified by PRV immunohistochemistry, presumably because of clearance of viruscontaining cells by an immune response (Rinaman et al., 1993; Card and Enquist, 1995).

Consistent with transneuronal passage of the virus, the pattern of labeling evolved in a predictable and ordered manner between cases. It should be stressed that there is no definitive evidence that PRV is transmitted strictly in a synaptic manner. Retrograde tracing from the Ce to the elPB and from the elPB to the spinal dorsal horn and trigeminal nucleus caudalis was similar to that obtained with Fluorogold, supporting the proposal that PRV travels in specific neural circuits. Also, the presence of discrete columns in the TNC after virus injection in the Ce argues against nonspecific spread of the virus from lamina I where it appears earliest to the immediately subjacent lamina II. Furthermore, in cases of diffuse labeling of lamina II, we 

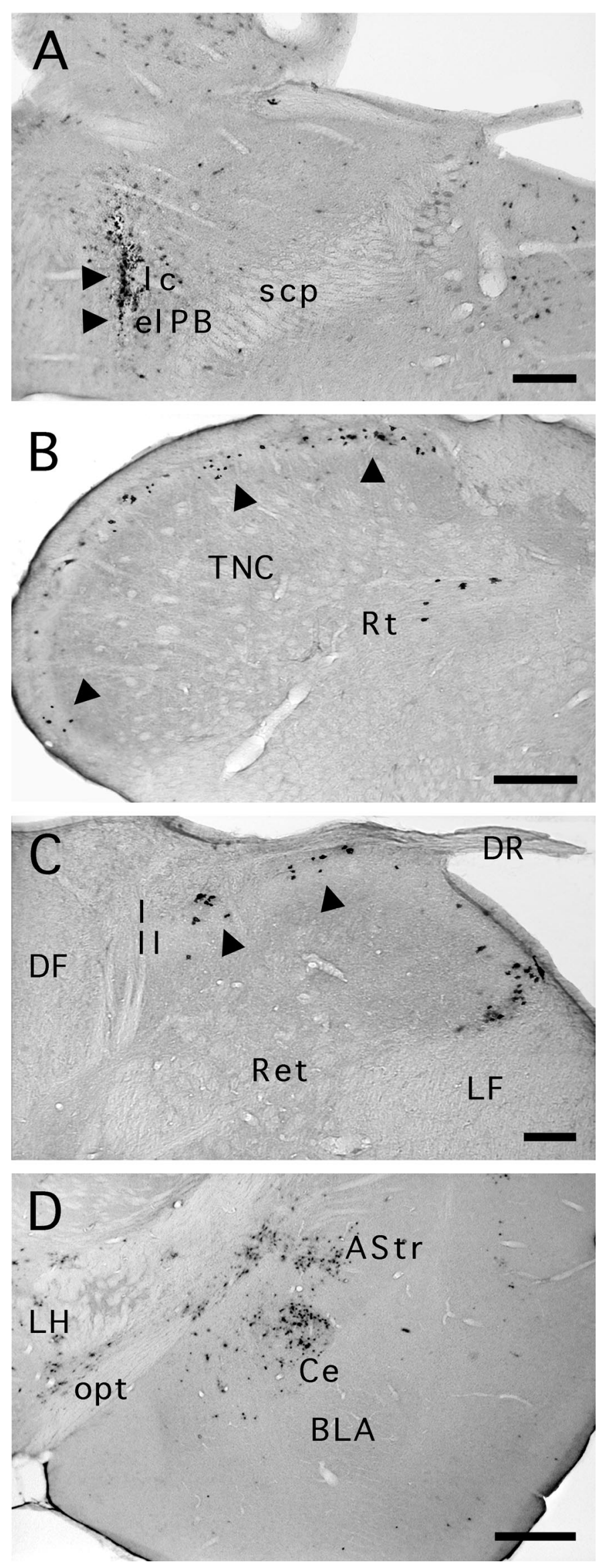

did not label neurons of the immediately adjacent lamina III. Finally, coincident PRV labeling of lamina II neurons and trigeminal ganglion neurons, at the longest survival times, supports previous evidence of convergent projections onto lamina I neurons (Willis and Coggeshall, 1991).

\section{Alternate pathways}

TNC and spinal inputs can reach the Ce through other routes, including the midline thalamic nuclei, the hypothalamus, the nucleus of the solitary tract, and the A1/lateral reticular medullary area (Ricardo and Koh, 1978; Veening, 1978; Ottersen and Ben-Ari, 1979; Roder and Ciriello, 1993). All these nuclei contained PRV-immunopositive neurons after injection in the $\mathrm{Ce}$ at survival times sufficient to permit only neurons with direct projections to be labeled. Bilateral lesions of the elPB with ibotenic acid, however, prevented most of the labeling of lamina I neurons of the TNC and spinal dorsal horn, whereas labeling in deeper laminae was preserved. Therefore, although some lamina I input to the Ce may be relayed by other structures, such as the nucleus of the solitary tract (Menétrey and Basbaum, 1987), the elPB seems to relay most of these afferents. This is consistent with previous reports that spinal and trigeminal afferents (either directly to the amygdala or to relay nuclei other than the nucleus of the solitary tract) originate predominantly from deep layers of the dorsal horn in the rat (Menétrey and de Pommery, 1991).

\section{Afferent connection of the amygdala arising from lamina I}

The presence of bilateral PRV labeling of lamina I neurons after Ce injection at both the medullary and spinal levels suggests an extensive convergence of nociceptive input from all parts of the body to the $\mathrm{Ce}$, consistent with a previous electrophysiological study (Bernard et al., 1992). Thus, lamina I neurons, many of which are nociceptive specific (Besson and Chaouch, 1987), are likely to contribute to the generalized emotional and motivational responses to noxious stimuli (Adolphs et al., 1995; LaBar et al., 1995; Maren and Fanselow, 1996).

Controversy has existed as to how spinal inputs are relayed via the $\mathrm{PB}$ to the $\mathrm{Ce}$, principally because spinal afferent terminals have not been detected in the elPB, where the majority of retrogradely labeled neurons from the Ce resides (Saper, 1995). The extensive dendritic labeling of elPB neurons after Fluoro-gold injections provides clues to how the connection is made. The dendrites of elPB neurons retrogradely labeled from the $\mathrm{Ce}$ extended into spinal lamina I terminal areas in the lateral parabrachial complex (Bernard et al., 1995; Feil and Herbert, 1995). Ultrastructural analysis has, in fact, demonstrated synaptic contacts between spinal afferents and the dendrites of amygdala-

Figure 11. Case 103. A, PRV coinjected with gold particles (arrowheads) into the $e l P B$ and lateral crescent area $(l c)$ nuclei of the parabrachial complex. $B$, PRV immunolabeling in the caudal medulla $56 \mathrm{hr}$ after injection. We recorded clusters of labeled neurons (arrowheads) that spanned laminae I throughout the extent of the trigeminal nucleus caudalis $(T N C)$ and occasionally encroached on lamina II. Although we found no labeled cells in the deeper laminae of the TNC, some were found in the reticular formation $(R t)$. PRV immunolabeling in the cervical spinal cord (C) revealed neuronal clusters in laminae I and II (arrowheads). D, Retrograde PRV labeling was also found in the central nucleus of the amygdala $(\mathrm{Ce})$, the amygdalostriatal junction $(A S t r)$, and the lateral hypothalamus $(L H)$ after this elPB injection. Basolateral amygdaloid nucleus, anterior $(B L A)$; dorsal root $(D R)$; dorsal funiculus $(D F)$; lateral funiculus $(L F)$; optic tract (opt); reticulated area of the spinal dorsal horn $($ Ret). Scale bars: $A, B, D, 250 \mu \mathrm{m} ; C, 125 \mu \mathrm{m}$. 

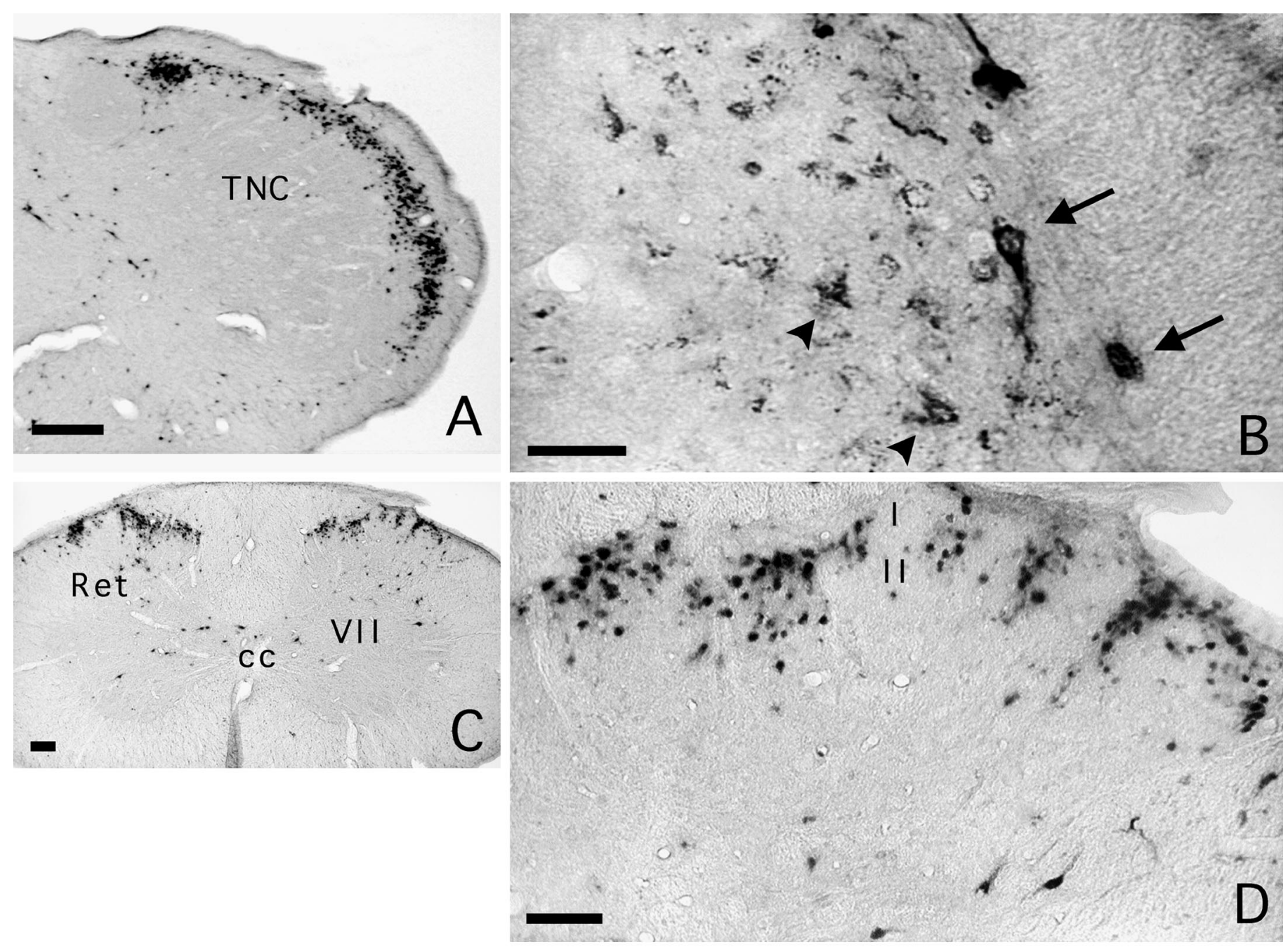

Figure 12. Case 51. A, PRV immunolabeling in the caudal medulla $96 \mathrm{hr}$ after coinjection of PRV and CTB in the elPB. Densely packed PRV-immunopositive neurons were found throughout the extent of laminae I and II of the trigeminal nucleus caudalis (TNC). The abundance of labeling obscured the columnar organization. $B$, Double labeling for cholera toxin B and PRV demonstrated cholera toxin B-immunoreactive neurons; these were largely restricted to lamina I (arrows) and were always immunoreactive for PRV. PRV-immunoreactive neurons (arrowheads) were seen to underlie double-labeled lamina I neurons (arrows). Compared with Figure $8 B$, the cholera toxin-labeled lamina I neurons appear atrophic and their dendritic tree is not evident. This is likely attributable to a longer $(\sim 24 \mathrm{hr})$ presence of viral replication in these cells. $C$, PRV immunolabeling in the cervical spinal cord demonstrated elongated, radially oriented neuronal columns that spanned laminae I and II; the columns are spaced at regular intervals (130-360 $\mu \mathrm{m})$. Isolated PRV cells are also seen in the reticulated part of the dorsal horn (Ret), the area surrounding the central canal (cc), and in lamina VII of the ventral horn. $D$, At higher magnification, it is apparent that the columnar immunolabeling is restricted to laminae I and II, and that some bridging of columns has begun to occur in lamina I such that at later survivals, the columns could be obscured. Scale bars: $A, 300 \mu \mathrm{m} ; B, 175 \mu \mathrm{m} ; C, 50 \mu \mathrm{m} ; D$, $100 \mu \mathrm{m}$.

projecting neurons in the lateral parabrachial area (Ma and Peschanski, 1988). Together with the sequential and temporally separate infection of neurons in the elPB and in lamina I neurons of the medulla and spinal cord, we conclude that transneuronal passage of the virus occurred from the dendrites of elPB neurons to the axon terminals of lamina I afferents in the external nuclear layer of the parabrachial complex.

\section{Transneuronal labeling of inputs to the lamina I projection neuron}

Both trigeminal primary sensory neurons and lamina II neurons were consistently labeled within $24 \mathrm{hr}$ after the first appearance of PRV immunoreactivity in neurons of lamina I, providing evidence that lamina I projection cells receive direct input from both primary afferents and from underlying lamina II cells (Gobel, 1978a,b; Hoheisel and Mense, 1989; Sugiura et al., 1993). Double labeling of trigeminal ganglion neurons for PRV and substance P suggests that these lamina I projection neurons are acted on by peptide-containing nociceptive primary afferents, consistent with recent reports (Ding et al., 1995a,b) demonstrating that some lamina I neurons that project to the parabrachial complex express the substance $\mathrm{P}$ receptor. Although we could not discern the morphology of the lamina II neurons, some presumably correspond to the stalk cell, a proposed excitatory interneuron, the axon of which arborizes exclusively in lamina I (Bennett et al., 1980). On the other hand, because columns of cells were found throughout the depths of the substantia gelatinosa, it is likely that there was also labeling of the islet cells that populate the substantia gelatinosa. Many of the latter are inhibitory interneurons, the axonal and dendritic processes of which are confined to lamina II. The retrograde transport of cholera toxin in lamina I parabrachial 
projection neurons demonstrated that dendritic processes extend into lamina II and could therefore be responsible for the retrograde passage of PRV directly from lamina I neurons to islet cells. PRV double labeling of neurons within lamina II columns with antibodies against various neurotransmitters may provide insight into the regulation of lamina I projection neurons.

The columnar pattern of viral labeling suggests that viral transmission occurs within isolated compartments or modules containing functionally related neurons. We have observed previously columnar labeling of the superficial dorsal horn after peripheral PRV injection (Jasmin et al., 1997), which is consistent with the columnar pattern of labeling in the superficial dorsal horn produced by anterograde labeling of primary sensory afferents from dorsal root ganglia (Arvidsson and Pfaller, 1990; see their Figs. 3, 7, 9, 10). Simultaneous recordings from neurons in laminae I and II of the primate demonstrated that interneurons of the substantia gelatinosa provided excitatory inputs to adjoined lamina I neurons (Price et al., 1979). Our results, which determined a temporally coincident labeling of substantia gelatinosa interneurons and primary afferents in the trigeminal ganglia, indicate that lamina I neurons at the origin of the spino-parabrachio-amygdaloid pathway receive a convergent input from both sources. The dual excitatory drive received by these neurons could provide the anatomical basis for the finding that some lamina I spinoparabrachial neurons remain active, despite high doses of systemic morphine (Jasmin et al., 1994). It has been postulated that the activity of these neurons is required for eliciting descending inhibition, a function that has been ascribed to the Ce (Manning and Mayer, 1995).

\section{REFERENCES}

Adolphs R, Tranel D, Damasio H, Damasio AR (1995) Fear and the human amygdala. J Neurosci 15:5879-5891.

Amaral DG, Price JL, Pitkänen A, Carmichael ST (1992) Anatomical organization of the primate amygdala. In: The amygdala (Aggleton JP, ed) pp 1-66. New York: Wiley.

Arvidsson J, Pfaller K (1990) Central projections of C4-C8 dorsal root ganglia in the rat studied by anterograde transport of WGA-HRP. J Comp Neurol 292:349-362.

Bennett GJ, Abdelmoumene M, Hayashi H, Dubner R (1980) Physiology and morphology of substantia gelatinosa neurons intracellularly stained with horseradish peroxidase. J Comp Neurol 194:809-827.

Bernard JF, Besson JM (1990) The spino(trigemino)pontoamygdaloid pathway: electrophysiological evidence for an involvement in pain processes. J Neurophysiol 63:473-490.

Bernard JF, Besson JM (1992) Ascending pain pathways with special reference to the spino(trigeminal)-ponto-amygdaloid tract. In: Toward the use of noradrenergic agonists for the treatment of pain (Besson JM, Guilbaud G, eds), pp 1-25. New York: Elsevier.

Bernard JF, Huang GF, Besson JM (1992) Nucleus centralis of the amygdala and the globus pallidus ventralis: electrophysiological evidence for an involvement in pain processes. J Neurophysiol 68:551-569.

Bernard JF, Dallel R, Raboisson P, Villanueva L, Le Bars D (1995) Organization of the efferent projections from the spinal cervical enlargement to the parabrachial area and periaqueductal gray: a PHA-L study in the rat. J Comp Neurol 353:480-505.

Besson JM, Chaouch A (1987) Peripheral and spinal mechanisms of nociception. Physiol Rev 67:67-186.

Blomqvist A, Ma W, Berkley KJ (1989) Spinal input to the parabrachial nucleus in the cat. Brain Res 480:29-36.

Card JP, Enquist L (1995) Neurovirulence of pseudorabies virus. Crit Rev Neurobiol 9:137-162.

Card JP, Enquist LW (1994) Use of pseudorabies virus for definition of synaptically linked populations of neurons. In: Methods in molecular genetics (Adolph KW, ed), pp 363-382. New York: Academic.

Card JP, Rinaman L, Schwaber JS, Miselis RR, Whealy ME, Robbins AK, Enquist LW (1990) Neurotropic properties of pseudorabies virus: up- take and transneuronal passage in the rat central nervous system. J Neurosci 10:1974-1994.

Card JP, Whealy ME, Robbins AK, Moore RY, Enquist LW (1991) Two alpha-herpesvirus strains are transported differentially in the rodent visual system. Neuron 6:957-969.

Ding YQ, Takada M, Shigemoto R, Mizuno N (1995a) Spinoparabrachial tract neurons showing substance $\mathrm{P}$ receptor-like immunoreactivity in the lumbar spinal cord of the rat. Brain Res 674:336-340.

Ding YQ, Takada M, Shigemoto R, Mizuno N (1995b) Trigeminoparabrachial projection neurons showing substance $\mathrm{P}$ receptor-like immunoreactivity in the rat. Neurosci Res 23:415-418.

Feil K, Herbert H (1995) Topographic organization of spinal and trigeminal somatosensory pathways to the rat parabrachial and Kölliker-Fuse nuclei. J Comp Neurol 353:506-528.

Fuxe K, Chadi G, Tinner B, Agnati LF, Pettersson R, David G (1994) On the regional distribution of heparan sulfate proteoglycan immunoreactivity in the rat brain. Brain Res 636:131-138.

Gobel S (1978a) Golgi studies of the neurons in layer I of the dorsal horn of the medulla (trigeminal nucleus caudalis). J Comp Neurol 180:375-394.

Gobel S (1978b) Golgi studies of the neurons in layer II of the dorsal horn of the medulla (trigeminal nucleus caudalis). J Comp Neurol 180:395-414.

Hoheisel U, Mense S (1989) Spinal projections of thin myelinated deep afferents and their topical relation to dorsal horn neurones processing deep input. In: Processing of sensory information in the superficial dorsal horn of the spinal cord (Cervero F, Bennett GJ, Headley PM, eds), pp 29-40. New York: Plenum.

Iadecola C, Arneric SP, Baker HD, Tuker LW, Reis DJ (1987) Role of local neurons in cerebrocortical vasodilatation elicited from the cerebellum. Am J Physiol 252:1082-1091.

Jasmin L, Wang H, Tarczy-Hornoch K, Levine JD, Basbaum AI (1994) Differential effects of morphine on noxious stimulus-evoked Fos-like immunoreactivity in subpopulations of spinoparabrachial neurons. J Neurosci 14:7252-7260.

Jasmin L, Carstens E, Basbaum AI (1997) Interneurons presynaptic to rat tail-flick motoneurons as mapped by transneuronal transport of pseudorabies virus: few have long ascending collaterals. Neuroscience 76:859-876.

Karger A, Saalmüller A, Tufaro F, Banfield BW, Mettenleiter TC (1995) Cell surface proteoglycans are not essential for infection by pseudorabies virus. J Virol 69:3482-3489.

Kaufman GD, Mustari MJ, Miselis RR, Perachio AA (1996) Transneuronal pathways to the vestibulocerebellum. J Comp Neurol 370:501-523.

Krettek JE, Price JL (1978) Amygdaloid projections to subcortical structures within the basal forebrain and brainstem in the rat and cat. J Comp Neurol 178:225-254.

LaBar KS, LeDoux JE, Spencer DD, Phelps EA (1995) Impaired fear conditioning following unilateral temporal lobectomy in humans. J Neurosci 15:6846-6855.

Llewellyn-Smith IJ, Minson JB (1992) Complete penetration of antibodies into vibratome sections after glutaraldehyde fixation and ethanol treatment: light and electron microscopy for neuropeptides. J Histochem Cytochem 40:1741-1749.

Loewy AD (1995) Pseudorabies virus: a transneuronal tracer for neuroanatomical studies. In: Viral vectors (Kaplitt MG, Loewy AD, eds), pp 349-366. Boston: Academic.

Ma W, Peschanski M (1988) Spinal and trigeminal projections to the parabrachial nucleus in the rat: electron-microscopic evidence of a spino-ponto-amygdalian somatosensory pathway. Somatosens Mot Res 5:247-257.

Manning BH, Mayer DJ (1995) The central nucleus of the amygdala contributes to the production of morphine antinociception in the rat tail-flick test. J Neurosci 15:8199-8213.

Marchand CF, Schwab M (1986) Binding, uptake and retrograde axonal transport of herpes virus in sympathetic neurons. Brain Res 383:262-270.

Maren S, Fanselow MS (1996) The amygdala and fear conditioning: has the nut been cracked? Neuron 16:237-240.

Martin X, Dolivo M (1983) Neuronal and transneuronal tracing in the trigeminal system of the rat using the herpes virus suis. Brain Res 273:253-276. 
Menétrey D, Basbaum AI (1987) Spinal and trigeminal projections to the nucleus of the solitary tract: a possible substrate for somatovisceral and viscerovisceral reflex activation. J Comp Neurol 255:439-450.

Menétrey D, de Pommery J (1991) Origins of spinal ascending pathways that reach central areas involved in visceroception and visceronociception in the rat. Eur $\mathrm{J}$ Neurosci 3:249-259.

Meunier M, Destrade C (1988) Electrolytic but not ibotenic acid lesions of the posterior cingulate cortex produce transitory facilitation of learning in mice. Behav Brain Res 27:161-173.

NIH (1988) Biosafety in microbiological and biomedical laboratories. Health and Human Services Publication 88-8395. Bethesda, MD: National Institutes of Health.

O’Donnell P, Lavín A, Enquist LW, Grace AA, Card JP (1997) Interconnected parallel circuits between rat nucleus accumbens and thalamus revealed by retrograde transynaptic transport of pseudorabies virus. J Neurosci 17:2143-2167.

Ottersen O, Ben-Ari Y (1979) Afferent connections to the amygdaloid complex of the rat and cat. I. projections from the thalamus. J Comp Neurol 187:401-424.

Paxinos G, Watson C (1986) The rat brain in stereotaxic coordinates. New York: Academic.

Pensaert MB, Kluge JP (1989) Pseudorabies virus (Aujeszky's disease). In: Virus infections of porcines (Pensaert MB, ed), pp 39-64. Amsterdam: Elsevier.

Pitkänen A, Stefanacci L, Farb CR, Go GG, LeDoux JE, Amaral DG (1995) Intrinsic connections of the rat amygdaloid complex: projections originating in the lateral nucleus. J Comp Neurol 356:288-310.

Price DD, Hayashi H, Dubner R, Ruda MA (1979) Functional relationships between neurons of marginal and substantia gelatinosa layers of primate dorsal horn. J Neurophysiol 42:1590-1608.

Ricardo JA, Koh ET (1978) Anatomical evidence of direct projections from the nucleus of the solitary tract to the hypothalamus, amygdala, and other forebrain structures in the rat. Brain Res 153:1-26.

Rinaman L, Card JP, Enquist LW (1993) Spatiotemporal responses of astrocytes, ramified microglia, and brain macrophages to central neuronal infection with pseudorabies virus. J Neurosci 13:685-702.
Roder S, Ciriello J (1993) Innervation of the amygdaloid complex by catecholaminergic cell groups of the ventrolateral medulla. J Comp Neurol 332:105-122.

Roizman B, Furlong D (1974) The replication of herpesviruses. In: Comprehensive virology (Fraenkel-Conrat H, Wagner RR, eds), pp 229403. New York: Plenum.

Rouiller EM, Capt M, Dolivo M, De Ribaupierre F (1986) Tensor tympani reflex pathways studied with retrograde horseradish peroxidase and transneural viral tracing techniques. Neurosci Lett 72:247-252.

Saper CB (1995) The spinoparabrachial pathway: shedding new light on an old path. J Comp Neurol 353:477-479.

Savander V, Go CG, LeDoux JE, Pitkänen A (1995) Intrinsic connections of the rat amygdaloid complex: projections originating in the basal nucleus. J Comp Neurol 361:345-368.

Scopsi L, Larsson LI (1985) Increased sensitivity in immunocytochemistry: effects of double application of antibodies and silver intensification on immunogold and peroxidase-antiperoxidase staining techniques. Histochemistry 82:321-329.

Smith Y, Paré D (1994) Intra-amygdaloid projections of the lateral nucleus in the cat: and glutamate immunocytochemistry. J Comp Neurol 342:232-248.

Spear PG (1993) Entry of alphaherpesviruses into cells. Semin Virol 4:167-180.

Strack AM, Loewy AD (1990) Pseudorabies virus: a highly specific transneuronal cell body marker in the sympathetic nervous system. J Neurosci 10:2139-2147.

Sugiura Y, Terui N, Hosoya Y, Tonosaki Y, Nishiyama K, Honda T (1993) Quantitative analysis of central terminal projections of visceral and somatic unmyelinated $(\mathrm{C})$ primary afferent fibers in the guinea pig. J Comp Neurol 332:315-325.

Swanson LW (1992) Brain maps: Structure of the rat brain. New York: Elsevier.

Veening JG (1978) Subcortical afferents of the amygdaloid complex in the rat: an HRP study. Neurosci Lett 8:197-202.

Willis WDJ, Coggeshall RE (1991) Sensory mechanisms of the spinal cord. New York: Plenum. 